December 17, 2004

\title{
Corporate Governance and Managerial Risk Taking: Theory and Evidence
}

\author{
Kose John*, Lubomir Litov ${ }^{* *}$, Bernard Yeung ${ }^{* * *}$
}

\begin{abstract}
We study how the investor protection environment affects corporate managers' incentives to take value-enhancing risks. In our model, the manager chooses higher perk consumption when investor protection is low. Since perks represent a priority claim held by the manager, lower investor protection leads the manager to implement a sub-optimally conservative investment policy, effectively aligning her risk-taking incentives with those of the debt holders. By the same token, higher investor protection is associated with riskier investment policy and faster firm growth. We test these predictions in a large Global Vantage panel. We find strong empirical confirmation that corporate risk-taking and firm growth rates are positively related to the quality of investor protection.
\end{abstract}

JEL Classification: G15, G31, G34.

Keywords: Corporate Governance, Investor Protection, Managerial Incentives.

* William Gerstenberg Professor of Banking and Finance, Stern School of Business, New York University, Tel: (212) 998-0337, Fax: (212) 995-4233, Email: kjohn@stern.nyu.edu

** Doctoral student, Stern School of Business, New York University, Tel: (212) 998-0883, Fax: (212) 995-4218, Email:1litov@stern.nyu.edu

${ }_{* * *}$ Abraham Krasnoff Professor in Global Business, Economics, and Management at Stern School of Business, New York University, Tel: (212) 998-0425, Fax: (212) 995-4221, Email: byeung@stern.nyu.edu

We thank Heitor Almeida, Yakov Amihud, David Backus, Matt Clayton, Art Durnev, Bill Greene, Jianping Mei, Todd Milburn, Holger Mueller, Darius Palia, Thomas Philippon, S. Abraham Ravid, Joshua Ronen, Anjan Thakor, S. Vish Viswanathan, Daniel Wolfenzon, Jeffrey Wurgler, David Yermack, the participants of the seminars at New York University, Rutgers University, and the participants of the Corporate Governance conference at Washington University-St. Louis for valuable discussions. 


\section{Introduction}

A central theme of the agency-theoretic view of corporate finance is that corporate insiders may not maximize shareholder value but instead pursue their self-interest. Recent research in corporate governance has focused on how the mechanisms to uncover insiders' diversion of corporate resources can constraint this agency behavior. Among others, Shleifer and Wolfenzon (2002) point out that increasing the probability of detection and the punishment for diversion of corporate resources results in higher firm value and lower cost of capital. In this paper we extend this framework to examine how the quality of investor protection, defined as ability to limit managerial diversion of cash flows, affects managerial investment choices.

In our model, the manager makes two choices: the amount of perks to consume and the choice of risk in the investment decision. There is incomplete contracting on these choices such that both decisions are made to maximize the manager's utility. The model is laid out in two stages: the investment choice is made at the first stage and the perk choice is made at the second stage. The optimal choice of perks is a function of the degree of investor protection and of managerial ownership (although the latter is assumed to be below one hundred percent due to a managerial wealth constraint). Interestingly, the perks that the manager anticipates consuming in the second stage have the potential to distort her choice of investment risk in the first stage. Since the managerial perks are "skimmed off the top," they are tantamount to the manager holding a priority claim on the company's cash flow. This has an incentive effect on the manager's investment risk choice as if she held the firm's debt of a value equal to the amount of the optimal perks, the well-known effect of concavifying the manager's objective function. Ultimately, anticipated perk consumption makes the manager more conservative in her 
investment risk choice than otherwise, and causes her to forgo risky projects that would be value enhancing to shareholders.

An improvement in investor protection, however, increases the expected cost of perk consumption and results in a lower optimal level of perks. This is equivalent to reducing the amount of "senior debt" that the manager holds and in turn ameliorates her sub-optimal conservatism. In other words, better technology in "catching" and "punishing" managerial diversion of resources reduces managers' inclination to forego risky but value enhancing projects.

The above result has important implications. First, it suggests a novel avenue by which better corporate governance enhances firm value. The relation between corporate governance and risk-taking has been hitherto largely unexplored. ${ }^{1}$ Second, to the extent that risky projects are associated with efforts to innovate and innovations are associated with growth, particularly productivity growth, our result suggests a new path by means of which better protection for investors' property rights may increase growth.

We use cross-country data from 1992 to 2002 for thirty-eight countries to test the propositions that better investor protection leads to higher risk-taking and in turn higher growth. To proxy for the "riskiness" of chosen investment projects we use the variation in firm level cash flow over total assets. We find that the measure is positively associated with proxies for shareholder rights suggested in La Porta et al. $(1997,1998)$ and with economic growth, including total factor productivity growth. These results are robust to including various controls suggested in the literature.

\footnotetext{
${ }^{1}$ Philippon (2002) suggests that corporate governance can help explain the increase in the firm-specific volatility in the US - yet though he links this to competition - competitive product markets contribute to volatile firm markups but to smoother path of the overall profitability. Similarly, Allen and Gale (2000) address the issue of corporate governance and competition.
} 
Since management might be able to manipulate cashflow (Ball, Kothari, Robin (2000) and Leuz, Nanda, Wysocki (2003)), one concern is that low cashflow volatility may indicate active income smoothing rather than genuinely low real volatility. That is, to the extent that income smoothing is less prevalent in high investor protection countries, the correlation between high cashflow volatility and high investor protection could be affected by a relationship between investor protection and income manipulation. We therefore also consider an imputed measure of risk-taking. We first select the country with the least earnings smoothing, which, according to Leuz et al. (2003) and Bhattacharya, Daouk, Welker (2002) is the United States. We then use that country's scaled corporate cashflow, based only on undiversified firms, to compute a benchmark volatility index for each 3-digit SIC industry. For each country, the weighted average of these industry-level volatility indices, weighted by the country's industry composition, captures the "risks" which the country's firms collectively undertake. Using the so-computed risk-taking measure we perform the same analysis as before and find stronger results.

Our line of argument - better investor protection leads to more value-enhancing managerial risk-taking and thus faster growth - is a part of a growing literature on the relationship between corporate governance, firm value, and growth. A long series of work, ranging from King, Levine (1993a, 1993b), Levine (1997), to Rajan, Zingales (1998) develop the positive causal chains that build from financial markets development to capital accumulation and to growth. In addition, Allen and Gale (1997) and Acemoglu and Zilibotti (1997) argue that economies that provide better risk-diversification tend to promote risk taking in investments and thus growth. Another long series of work, initiated by La Porta et al $(1997,1998)$ and followed up by many, e.g., Demirguç-Kunt, Maksimovic (1998), Beck, Levine (2002), Beck, Demirguç- 
Kunt, and Levine (2003), show that enforced property rights protection for outside shareholders contribute to financial market development and then growth. Yet another line focuses on capital markets as a device to allocate resources and thus contribute to growth, e.g., Wurgler (2000) and Fisman and Love (2003)). Morck, Yeung, Yu (2000), Durnev, Morck, and Yeung (2004), and Durnev, et al. (2004) emphasize that capital markets can carry out this resource allocation role better when investors are more informed and informativeness stems from secured investor's property rights. At a micro level of analysis, researchers have noticed the relationship between managerial incentive and risk-taking. For example, Hirshleifer and Thakor (1992) and Holmstrom and Ricarti Costa (1986) have argued that managers exhibit excessive managerial conservatism stemming from managerial career concerns.

The organization of the paper is as follows. Section II introduces our model that links managerial risk-taking behavior to investor protection and derives testable implications. Section III covers data and methodology. Section IV presents the empirical results and Section V concludes.

\section{A Basic Model}

\section{A. Set up}

This section presents a simple model that captures the essential aspects at play. As in Jensen and Meckling (1976) we assume that the manager's objective function has two components: perk consumption $\mathrm{P}$ and wealth $\mathrm{W}$. Her objective is thus $U(P, W)$. To simplify the exposition we will use a utility function that is additive in the utility of perk consumption and the utility of wealth. Further we will assume that the manager's utility of perks is concave in the level of 
perks consumed and the utility of wealth is linear. Combining these features the managerial objective function has the form $U(P, W)=W+G(P)$, where $G($.$) is a concave function.$

In most of the analysis we will work with a particular structure of managerial preferences for perk consumption, $G(P)=g \sqrt{P}$. Here $g$ is an index of the manager's propensity to consume perks. " $g$ " will be specified such that the optimal level of perks chosen by the manager is large enough to have an effect on the incentives of the manager; the details of this scaling will be discussed later.

Now we introduce the menu of investments available to the manager and the nature of incomplete contracting that is at the heart of the agency problems. The manager chooses between two available projects each requiring an identical investment outlay $I$ : (i) a risk free project (or a storage technology) that generates $I$ dollars with certainty (for simplicity but without loss of generality we normalize the risk-free return to be zero); and (ii) a risky project that generates either a high cash flow $H$ with a probability $q$, or a low cash flow $L$ with a probability $(1-q)$, where $\mathrm{H}>\mathrm{I}>\mathrm{L}^{2}$

We assume that $q$ is uniformly distributed between 0 and 1 and this distribution is common knowledge at $\mathrm{t}=0$. The value of $q$ becomes known only to the manager at $\mathrm{t}=1$ before she chooses between the risky and the risk-free project. It is assumed that $q$ is not verifiable and hence not contractible. The timeline of events is as follows:

1. At time $\mathrm{t}=0$, the manager is given an optimal compensation structure that involves $\alpha$ of equity (equity participation). We could allow the manager to draw in addition a salary from the company, but in the basic model and without loss of generality, we set the salary

\footnotetext{
${ }^{2}$ We have also looked into a more general menu of projects available to the manager. However, to emphasize the results of our theoretical work, and without loss of generality, we simplify the modeling by assuming the presence of a risk free project as in John and John (1993).
} 
equal to zero. ${ }^{3}$ The firm also sells outside claims of value exceeding the investment amount I required. These claims are rationally priced at $\mathrm{t}=0$ anticipating the investment policy to be implemented by the manager at $t=1$ and the perks she will consume at $t=2$. For simplicity, we will consider external equity as the only outside claim. This is without loss of generality since the split between debt and equity has no additional incentive effects in our model.

2. The manager learns $q$ and chooses between the risky and the risk-free project.

3. At $t=2$, the cashflow from the project is realized. From the realized cashflow $Y$, the manager appropriates an amount $P, P \leq Y$, as a perk. The residual cashflow is reported as earnings available for distribution to external claimholders (equity holders).

The manager's problem is thus a two-stage optimization. In the first stage the manager chooses between the risky investment project and the risk-free investment project conditional on the value of $q$ (the probability of success of the risky project) that she observes. In the second stage the cashflow from investment is realized, that is $Y=L$ or $H$ if the risky project is chosen or $Y=I$ if the risk free project is chosen. In the second stage optimization, for any realized value of $Y$ the manager chooses the optimal perk consumption $P, P \leq Y$.

We shall solve the problem by backward induction: determine the manager's optimal perk choice in the second stage, fold it backwards, and then determine the investment choice at the first stage. The level of perks optimally consumed by the manager is endogenously determined as a function of her preference for perks and the effectiveness of the legal system. There are several ways that researchers have modeled the effect of the legal system on the manager's utility for perk consumption; we follow a simple implementation. We use a

\footnotetext{
${ }^{3}$ The managerial salary $\mathrm{S}$ is deducted from the operating cashflows along with other relevant costs to arrive at realized cashflows from the project. With this interpretation a non-zero level of managerial salary would not alter any results that follow.
} 
parameter $\phi$ to denote the effectiveness of the legal system in disciplining managers and protecting the rights of outside investors. Specifically, $\phi$ is the probability that the manager's perk consumption is detected ( $\mathrm{P}$ is revealed) and the manager is punished. The legal system imposes costs on the manager such that she derives zero utility from consuming perks. Her utility then is limited to that from her contracted compensation, $\alpha(Y-P)^{+}$. On the other hand, with a probability $(1-\phi)$, her perk consumption goes undetected and she derives utility from both her perk consumption, $P$ and the contracted compensation $\alpha(Y-P)^{+}$. Note that in both cases the shareholders' cashflows are reduced by P.

In the managerial preference for perks $G(P)=g \sqrt{P}$, we need to parameterize the value of $g$, such that the manager's choice of perks is important enough to affect her investment choices and thus engenders agency costs. There are several ways to parameterize $g$ such that the optimal perk consumption is a non-trivial fraction of the firm's cashflows in the low state of the world (state $L$ ). We will discuss an appropriate parameterization of $g$ such that this is the case, after we characterize the optimal perk consumption in Lemma 1 to follow.

In the basic model of this section we will take $\alpha$ to be exogenous. Issues of endogenizing $\alpha$ will be addressed in the appendix. Since managerial wealth is only a small fraction of the firm, and the amount $I$ needed for investment has to be raised by selling external equity, the largest value of $\alpha$ that can be given to the manager will be limited to be a small fraction of the firm, assuming that personal wealth constraint is binding. The details of this argument will be spelled out in the next section.

\section{B. Solution}


Given the above setup, the objective of the manager for the second stage problem is

$$
\max _{P} \alpha(Y-P)^{+}+(1-\phi) g \sqrt{P}
$$

We characterize the optimal choice of perk consumption in lemma one.

\section{Lemma 1}

The optimal consumption of perks in the second stage problem is given by

$$
P=\min \left[Y, P_{0}\right]
$$

for $Y=L, I$, or $H$ and $P_{0}=(1-\phi)^{2} g^{2} / 4 \alpha^{2}$.

Proof: Let $Y>P_{0}$. Let $P_{H}, P_{L}$, and $P_{I}$ represent respective perk consumption in the high and low state of the risky project and in the risk-free project. The first order condition with respect to $P_{H}, P_{L}$, and $P_{I}$ are given by (we omit the subscript for brevity): $0=-\alpha+\frac{g(1-\phi)}{2 \sqrt{P}}$ which implies that the optimal perk consumption is $P_{0}=(1-\phi)^{2} g^{2} / 4 \alpha^{2}$. If $Y \leq P_{0}$ then the manager consumes all cash flow as perks. (Notice that the second derivative of her objective function is $-\frac{g(1-\phi)}{4 \sqrt{P^{3}}}<0$ which implies that the first derivative is positive at $P=Y<P_{0}$. Thus the manager is eager to consume more perks but she is constrained doing so by the available cashflows.) Thus we obtain equation (2). Q.E.D.

Remark: The incentive problems in investment policy that we discuss below are important only when the perk consumption by the manager is non-trivial. In our model we will parameterize the value of $g$, the manager's propensity to consume perks to be large enough such 
that the optimal perks that the manager consumes is a same order of magnitude as L, the lowest possible cash flow realization under the risky technology of the firm. From the form of the optimal perks characterized in Lemma 1 it should be clear that the optimal perks are an increasing function of $g$ and that for any firm of a given value $L$, there exist a corresponding value of $g$ such that this condition is satisfied. ${ }^{4}$

The expected utility of the manager at the optimal level of perk consumption in the second stage problem can be used to derive the solution to the first stage problem. That is, the investment policy undertaken at $\mathrm{t}=0$ maximizes the expected utility of the manager at that stage taking into account the optimal perk consumption derived in the second stage problem. The modeling framework borrows at this stage from John and John (1993). We start by defining important investment policy requirements and the first best investment benchmark.

Definition: The investment policy $\{\widetilde{q}\}$ will denote investing in the risky project for all $q \geq \widetilde{q}$ and investing in the risk-free project for $q<\widetilde{q}$.

Lemma 2: The investment policy $\{\bar{q}\}$ is the first best Pareto optimal investment rule where

$$
\bar{q}=\frac{I-L}{H-L}
$$

Proof: Under complete contracting, the shareholders would want to implement the valuemaximizing investment policy, i.e., accepting the risky project when its expected return exceeds

\footnotetext{
${ }^{4}$ Alternatively, if we had represented $G(P)=P^{\eta}, 0<\eta<1$, again the optimal perk consumption is monotonically increasing in $\eta$ and hence there exists some value of $\eta$, where $0<\eta<1$, such that the optimal perks is the same order of magnitude as $\mathrm{L}$. We can use that value of $\eta$ to parameterize the managerial utility for perk consumption.
} 
that of the risk free project, $\bar{q} H+(1-\bar{q}) L \geq I$. This is equivalent to implementing the investment policy $\{\bar{q}\}$ where $\bar{q}$ is given in equation (3). $\quad$ Q.E.D.

As in the proof of Lemma 1 , let $P_{H}, P_{I}$, and $P_{L}$ denote the perk consumption in states $\mathrm{Y}$ $=\mathrm{H}, \mathrm{I}$ and $\mathrm{L}$ respectively. Similarly let $W_{H}, W_{I}, W_{L}$ denote the manager's contractual compensation (wealth) equal to $\alpha\left(H-P_{H}\right)^{+}, \alpha\left(I-P_{I}\right)^{+}$, and $\alpha\left(L-P_{L}\right)^{+}$respectively. We will also denote as $U_{H}=U\left(P_{H}, W_{H}\right), U_{I}=U\left(P_{I}, W_{I}\right)$, and $U_{L}=U\left(P_{L}, W_{L}\right)$ the utility levels for the manager in states H, I, L respectively. ${ }^{5}$ Now we are ready to characterize the optimal investment decision taken by the manager in the first stage problem.

\section{Proposition 1}

The optimal investment policy for the second stage problem is $\{\widetilde{q}\}$ where $\widetilde{q}$ is given by

$$
\widetilde{q}=\frac{U_{I}-U_{L}}{U_{H}-U_{L}}
$$

Proof: For each level of $q$ such that $q U_{H}+(1-q) U_{L} \geq U_{I}$, the manager undertakes the risky project; otherwise she will undertake the risk-free project. This is equivalent to implementing the investment policy $\{\widetilde{q}\}$, where $\widetilde{q}$ is given in equation (4). Q.E.D.

Remark: To illustrate Proposition 1, consider the following case. Let $L>P_{0}$. In this case notice that $\widetilde{q}=\frac{I-L}{H-L} \equiv \bar{q}$. When $L>P_{0}$ the investment policy chosen by the perk-consuming

\footnotetext{
${ }^{5}$ The contingent payoffs are as follows. For $Y>P_{0}$, where $\mathrm{Y}=\mathrm{L}$, I, or $\mathrm{H}$, the utility of the manager is $U(P, W)=\alpha\left(Y-\frac{(1-\phi)^{2} g^{2}}{4 \alpha^{2}}\right)+(1-\phi) g \sqrt{\frac{(1-\phi)^{2} g^{2}}{4 \alpha^{2}}}$ which is equal to $\alpha Y+\frac{(1-\phi)^{2} g^{2}}{4 \alpha}$ equal to $\alpha\left(Y+P_{0}\right)$. If $Y \leq P_{0}$ utility will be $U(P, W)=(1-\phi) g \sqrt{Y}$. Using these we characterize the expected payoff of the two projects.
} 
manager is the same as the one with complete contracting. The rationale is as follows. When the optimal perk consumption $\mathrm{P}_{0}$ is sufficiently low $(<L)$ such that even in the unlucky low state perk consumption is not jeopardized, there is no investment distortion. However, as we summarize in the following proposition, when perk consumption is higher than the minimally available cashflow the managerial investment policy is sub-optimal: in these instances perk consumption is similar to risky debt held by the manager, and she implements an investment policy that is sub-optimally conservative.

\section{Proposition 2}

The investment policy implemented in the second stage is:

(a) $\widetilde{q}=\bar{q}$ if $L \geq P_{0}$,

(b) $\tilde{q}=\frac{I-L+A}{H-L+A}>\bar{q}$ if $I>P_{0}>L$

(c) $\tilde{q}=\frac{(1-\phi) g(\sqrt{I}-\sqrt{L})}{\alpha H+\frac{(1-\phi)^{2} g^{2}}{4 \alpha}-(1-\phi) g \sqrt{L}}>\bar{q}$ if $H>P_{0} \geq I$

where $A=\left(\sqrt{L}-\frac{(1-\phi) g}{2 \alpha}\right)^{2} \geq 0$

Thus, the manager will invest in the risky project less often than what is optimal under the Pareto investment policy, $\widetilde{q}>\bar{q}$, if $P_{0}>L$. 
Proof: See Appendix. ${ }^{6}$

The implication is that the manager who appropriates company cashflow for personal benefits will forgo risky projects within $q \in[\bar{q}, \widetilde{q}), \widetilde{q}>\bar{q}$, when $P_{0}>L$. The intuition is as follows. In the low payoff state of a risky project, the insider's perk consumption will be limited to L. Therefore, she would adopt a risky project only when the high payoff state is considerable and likely enough to compensate for the lost "perks" in the low payoff state: there exists a subset of risky projects whose high payoff state is not sufficiently high and likely enough so that the manager will optimally relinquish these. Yet, these projects would have been accepted in a world of complete contracting. ${ }^{7}$

We now evaluate the impact of an improvement in $\phi$, the effectiveness of the legal system in disciplining managers on the riskiness of the investment policy implemented and its effect on the value of the firm.

\section{Proposition 3}

For $P_{0}>L$, an increase in $\phi$ (the effectiveness of the legal regime) will make the manager undertake the risky projects more frequently, $\frac{\partial \widetilde{q}}{\partial \phi}<0$. This higher risk-taking is in the direction

\footnotetext{
${ }^{6}$ We omit the case $P_{0} \geq H$ since the problem we study is not well defined when the optimal perk consumption exceeds the maximum project cashflow. It is straightforward to show that in this case the optimal investment policy is $\widetilde{q}=\frac{\sqrt{I}-\sqrt{L}}{\sqrt{H}-\sqrt{L}} \geq \bar{q}$, and thus this case conforms to Proposition 2 .

${ }^{7}$ Some may argue that the constraint on perk consumption in the low payoff state of a risky investment is not applicable to a large, cash-rich company. However, we believe that our intuition - low payoffs in low return states constrain perk consumption and thus managers avoid risky investment projects whose high payoffs in high return states do not adequately compensate for the perk reduction - is general. We could easily present a model in which investment payoffs are always adequate to cover perk consumption and yet revelation of perk consumption is more likely in low pay off states. Such a model will generate qualitatively similar results as the current model.
} 
of the first-best investment risk level and so is accompanied by higher expected growth rates, $\frac{\partial V(\widetilde{q})}{\partial \widetilde{q}}<0$

Proof: See Appendix.

Remark: With an increase in $\phi$, the probability of being caught diverting cash flow, the manager implements a riskier investment policy $\{\widetilde{q}\}$, i.e. she uses a lower cut-off level $\widetilde{q}$ for risky investments. Since $\tilde{q}>\bar{q}$, a lower cut-off level results in higher firm value. There are two implications. The first is that an improvement in detecting management's cashflow diversion raises the riskiness of the distribution of adopted projects. The second is that this increase in the riskiness of the distribution is desirable: it will be accompanied by an increase in the expected net present value. To see that, we have to first calculate the present value of investment project's from the investors' point of view. Investors do not know the value of $q$, but only that $q$ is uniformly distributed on $[0,1]$. Based on this, the net present value expected by investors is: ${ }^{8}$

$$
V(\widetilde{q})=-I+\widetilde{q} I+\frac{L}{2}(1-\widetilde{q})^{2}+\frac{H}{2}\left(1-\widetilde{q}^{2}\right)
$$

Differentiating $V(\widetilde{q})$ with respect to $\widetilde{q}$, for the perk-consuming insider yields:

$$
\frac{\partial V(\widetilde{q})}{\partial \widetilde{q}}=I-L-(H-L) \widetilde{q}<0
$$

The latter has a negative sign because $\widetilde{q}>\bar{q}$ (see Proposition 2). The intuition is as follows. A perk-consuming manager will tend to be overly conservative in order to preserve her perk More precisely, the net present value expected by equity holders is
$V(\widetilde{q})=-I+I \int_{0}^{\widetilde{q}} d q+L \int_{\widetilde{q}}^{1}(1-q) d q+H \int_{\widetilde{q}}^{1} q d q$. 
consumption, much like a debt-holder would want a company to take less risk to preserve the value of her contingency claims. Notice that, however, the manager may forgo risky projects that increase expected firm value. When better investor protection reduces the level of optimal perk consumption, the manager implements higher-valued and higher-risk investment policy.

Our results are derived assuming that the manager's incentives $(\alpha)$ are exogenous. In equilibrium, incentives will be set to offset manager's excess risk aversion. In the appendix, we show that allowing an endogenously determined incentive $\alpha$ does not change our results as long as the manager faces a personal wealth constraint.

In summary, our contribution here lies in providing a novel mechanism for explaining why corporate governance matters for growth. Specifically, Proposition 3 leads to several empirical hypotheses:

1. Better investors protection, especially better disclosure rules and more effective monitoring of manager's behavior, will result in greater managerial risk taking;

2. Higher risk-taking leads to higher firm growth; and,

3. Because the risk-taking is value-enhancing, the volatility of investment returns in highdisclosure and effective-monitoring countries are associated with greater country level growth in GDP and productivity.

\section{Empirical Implications and Tests}

We test these main empirical predictions using Compustat Global Vantage data for thirtyeight countries in the period 1992-2002. A cross-country study is appropriate because variation in corporate accountability across countries is more likely to be exogenous than variations within countries. The empirical work entails regressing firm level and country-level observations of 
"risk-taking" in corporate operations on variables that capture corporate accountability, controlling for other relevant factors. We also regress firm- and country-level growth measure (including country-level total factor productivity growth) on "risk-taking" in corporate operations, controlling for corporate accountability and other factors to test the mechanism that Proposition 3 implies. The regression specifications are as follows:

$$
\begin{aligned}
& \operatorname{RISK}_{c}=\alpha_{1}+\alpha_{2} \text { ACCOUNTABI LITY }_{c}+\alpha_{3} \mathrm{X}_{c}+\omega_{c} \\
& \operatorname{RGDP}_{c}=\beta_{1}+\beta_{2} R I S K_{c}+\beta_{3} \mathrm{Y}_{c}+\vartheta_{c} \\
& \operatorname{TFP}_{c}=\gamma_{1}+\gamma_{2} \operatorname{RISK}_{c}+\gamma_{3} \mathrm{Z}_{c}+\varsigma_{c}
\end{aligned}
$$

where the subscripts $c$ indicates country, RISK is a proxy for risk-taking in corporate operations, ACCOUNTABILITY is a proxy for corporate accountability, RGDP is the per-capita real GDP growth, TFP is the total factor productivity growth, and $\mathrm{X}_{\mathrm{c}}, \mathrm{Y}_{\mathrm{c}}$, and $\mathrm{Z}_{\mathrm{c}}$ are matrices of control variables. Our first empirical hypothesis implies that $\alpha_{2}$ is positive while the third empirical hypothesis implies $\beta_{2}$ and $\gamma_{2}$ are positive. Our second empirical hypothesis implies that a firm level data regression analogous to (11) but replacing country level growth by firm level growth also generates a positive $\beta_{2}$. Note that in regressions (11) and (12), we will include as controls the "corporate accountability" variables. If indeed these controls explain the variation in the risk-taking measure, then we would expect that including them in the regression will lower the explanatory power of that measure. Nevertheless, by including them as controls we can identify whether risk taking per se affects growth. 


\section{A. Description of Variables}

Below is an extended description of how we construct our key variables. See Table 1 for a concise reference.

\section{A.1. Measuring risk taking}

Ideally, to measure the true choice of the underlying economic risk, we would like to have something like the probability of success, $q$, in the model. Of course, this is unobservable. However, since riskier corporate operations have more volatile returns to capital, we develop three proxies for the degree of risk-taking in firm's operations: (i) the industry-adjusted volatility of firm-level profitability over the sample period 1992-2002; (ii) a country average of the volatility of firm profitability; and (iii) an imputed country risk score, based on industry risk characteristics. We describe them in turn.

\section{$\underline{\text { RISK1 }}$}

Our first measure of risk-taking (RISK1) is $\sigma_{i, c}=\sqrt{\frac{1}{T-1} \sum_{t=1}^{T}\left(E_{i, c, t}-\frac{1}{T} \sum_{t=1}^{T} E_{i, c, t}\right)^{2}} \mid T \geq 5$, where $E_{i, c, t}=\frac{E B I T D A_{i, c, t}}{A_{i, c, t}}-\frac{1}{N_{c, t}} \sum_{k=1}^{N_{c, t}} \frac{E B I T D A_{k, c, t}}{A_{k, c, t}}$, and $\mathrm{N}_{\mathrm{c}, \mathrm{t}}$ is the total number of firms within country $\mathrm{c}$ for year t. That is, for each firm with available earnings and total assets for at least five years across 1992-2002, we compute the deviation of the firm's EBITDA/Assets from the country average for the corresponding year. We then calculate the standard deviation of this measure, for each firm (subtracting $\frac{1}{T} \sum_{t=1}^{T} E_{i, c, t}$ from $E_{i, c, t}$ has the effect of taking away the time invariant firm-specific factor in EBITDA/Asset). Hence, each firm receives a single value. EBITDA is the sum of depreciation and amortization (data item \#11) and operating income after depreciation 
(data item \#14), scaled by the contemporaneous total assets (data item \#89). Prior to computing the risk-taking proxy, the demeaned profitability measure $E_{i, c, t}$ is winsorized at $0.5 \%$ in both tails of the distribution to account for possible data errors.

\section{$\underline{\text { RISK2 }}$}

We use $\sigma_{i, c}$ as the dependent variable in regression (10). This sampling gives more weight to countries with more firms. To address this bias, we also use a second measure, the average of $\sigma_{i, c}$ within a given country so that each country has only one observation. We denote this $\sigma_{c}$ (RISK2).

Regression (10) aims to identify association between return volatility and corporate accountability. The $\sigma_{i, c}$ and $\sigma_{c}$ measures, however, may be influenced by firm level income smoothing (Ball et al. (2000) and Leuz et al. (2003).) If income smoothing is more aggressive and more prevalent in countries with low corporate accountability, it may render $\sigma_{i, c}$ and $\sigma_{c}$ lower; in that case, observing lower risk-taking in countries with low corporate accountability may not imply that firms in the latter undertake less risky operations.

\section{$\underline{\text { RISK3 }}$}

While we attempt to control for the potential firm level income smoothing in specifications of (10), we also address the concern with an imputed measure of risk-taking. First,

we use US earnings data to compute an industry-by-industry risk score, $\sigma_{1994-1997, j}^{\text {USA }}$, based on the observation that US cashflow data, while certainly not perfect, is subject to less earnings smoothing than data from other countries (Leuz et al. (2003) and Bhattacharya et al. (2002)). 
$\sigma^{U S A}{ }_{1994-1997, j}$ is the variation of $E_{i, j, t}^{U S A}=\left(E B I T D A_{i, j, t}^{U S A} / A_{i, j, t}^{U S A}\right)-\frac{1}{N_{t}^{U S A}} \sum_{j} \sum_{i=1}^{N_{j}}\left(E B I T D A_{i, j, t}^{U S A} / A_{i, j, t}^{U S A}\right)$ in the period 1994-1997 defined as $\left[\frac{1}{\sum_{t=1994}^{t=1997} N_{j, t}^{U S A}-1} \sum_{t=1994}^{1997} \sum_{i=1}^{N_{j}}\left(E^{U S A} A_{i, j, t}-\frac{1}{\sum_{t=1994}^{t=1997} N_{j, t}^{U S A}} \sum_{t=1994}^{1997} \sum_{i=1}^{N_{j}} E^{U S A}\right)_{i, j, t}\right)^{0.5}$ where $j$ indexes the 3-digit SIC codes for manufacturing industries, $i$ indexes the undiversified companies within a given industry, $t$ indexes the years 1994-1997 and $N_{j, t}^{U S A}$ represents the number of firms in the US in industry $j$ in year $t$. By construction, $\left[E^{U S A_{i, j, t}}-\frac{1}{\sum_{t=1994} N_{j, t}^{U S A}} \sum_{t=1994}^{1997} \sum_{i=1}^{N_{j, t}^{U S A}} E^{U S A_{i, j, t}}\right]$ captures the deviation of a firm's EBITDA/Assets from industry $j$ 's average in year $t$, and also the deviation of industry j's average EBITDA/Assets in year t from its sample average, but the deviation of economywide average in year $\mathrm{t}$ from its sample average is netted out. $\sigma_{1994-1997, j}^{\text {USA }}$ captures the corresponding variance measure.

Prior to computing $\sigma_{1994-1997, j}^{U S A}$ we winsorize $E_{i, j, t}^{U S A}$ at $0.5 \%$ in both tails of its distribution to account for data errors. We use only single business segment firms, identified through the Compustat segments file. EBITDA ${ }_{i, j, t}^{U S A}$ is data item \#13 (Operating Income Before Depreciation) and $A_{i, j, t}^{U S A}$ refers to data item \#6 (Total Assets), both from Compustat North America for 1994-1997. We start in 1994 in order to exclude the recession years preceding 1994. The sample ends in 1997 because business unit reporting changed in that year (in 1997 , FAS 131 changed the way companies reported their segments, rendering comparisons of US segments pre- and post-1998 difficult). We include only firms with sales of at least \$10 million.

We use $\sigma_{1994-1997, j}^{\text {USA }}$ to impute the score of country "risk-taking." The score is calculated for each country over 1992-2002 (in table 5 panels A and B) or 1992-2000 (in table 5 
panel C.) The imputed risk scores are obtained as follows: $\Omega_{c}=\frac{1}{11} \sum_{t=1992}^{t=2002}\left(\sum_{j \in\{200, \ldots, 399\}} M V_{t, j, c} \times \sigma^{U S A}{ }_{1994-1997, j} / \sum_{j \in\{200, \ldots, 399\}} M V_{t, j, c}\right)$, where $j$ is an industry subscript based on 3digit SIC codes, $c$ is a country subscript, $t$ is a year subscript, $M V_{t, j, c}$ is the total market capitalization of companies in industry $j$ in year $t$ in country $c$. We name that RISK3. The concept of constructing this index is that countries that have allocated more investments into “riskier" industries will have a higher $\Omega_{c}$ score.

In computing $\Omega_{c}$ we include only firms with sales above $\$ 10$ million. Market capitalizations (MV) are computed as of the end of the fiscal year. Prices and shares outstanding for the sample firms are compiled from Compustat Global Issue database. Thus, $\Omega_{c}$ is the simple average over 1992 - 2002 of country c's annual value-weighted average of risk scores, $\sigma^{U S A}{ }_{1994-1997, j}$.

\section{A.2. Measuring corporate accountability}

To characterize corporate accountability in each country, we use three measures: the quality of accounting standards or disclosure (ASR), the rule of law (RL), and an index of antidirector rights (ADR). We use accounting standards as a proxy for corporate accountability since it represents the level of company disclosure within a country. The presumption is that higher disclosure makes corporate resources diversion more difficult. The variable is retrieved from La Porta et al. (1998) who tabulate the original data from the Center for International Financial Analysis and Research. ${ }^{9}$

\footnotetext{
${ }^{9}$ The variable represents a count of the inclusion or omission of 90 accounting items in a sample of 1990 annual reports. These items fall into seven categories (general information, income statements, balance sheets, fund flow statement, accounting standards, stock data, and special items).
} 
We supplement accounting standards (ASR) with the rule of law (RL) as an indicator of the effectiveness of enforcement of the regulations. The source of the data is also La Porta et al. (1998). RL is calculated as "average of the months of April and October of the monthly index between 1982 and 1995." The scale of this variable is from zero to 10, with lower scores for less tradition for law and order.

Third, we include the anti-director rights index (from La Porta et al. (1998)) as a gauge of the level of protection of shareholders from managerial stealing (Table 1 spells out the index details.)

The institutional measures are dated in 1990 or mid nineties and our data sample is from 1992 to 2002 . In spite of these time differences, the data are likely to represent the institutional environment in our sample period fairly well to the extent that institutional regimes tend not to change rapidly.

\section{A.3. Measuring growth}

Firm level growth is measured as the average of the growth in total assets (item \#89) and in sales (item $\# 1$ ) over the sample period, 1992-2002. Prior to computing the growth measures we convert all accounting data items into US\$ at the average monthly exchange rate as of the fiscal year end month. We winsorize the average assets and sales growth variables at the $0.5 \%$ level on both sides of the distribution.

For country growth we use two measures: real per-capita GDP growth and Total Factor Productivity (TFP) growth. Real GDP is measured in 1995 constant US\$. The nominal GDP, the GDP deflator and population data are obtained from the International Financial Statistics of the IMF. To measure TFP we follow the algorithm in King and Levine (1993a, 1993b). We use 
the recursive formulation, $K_{c, t+1}=K_{c, t}+I_{c, t}-\delta K_{c, t}$, where $c$ and $t$ are country and time subscripts. $K$ and I are, respectively, the real capital stock and real investment in country $\mathrm{c}$ in year $t$, and $\delta$ is the rate of depreciation, which we set to $7 \%$ as in the above mentioned studies. We start the recursion by assuming that the capital stock is zero in 1950 (the beginning of the data provided by Penn World Tables (PWT) version 6.1). Iterating forward we obtain the capital stock for each year in 1992-2000 (currently the last date with available data in PWT). We then define capital stock per capita, $k$, as the ratio of the real capital stock to the population. The productivity growth is finally defined as $\Delta \ln (y)-0.3 \Delta \ln (k)$, where the capital stock intensity is assumed to be $30 \%$ across all countries.

\section{A.4. Control Variables}

\section{Competition}

The vector of control variables in regression (10) includes factors known to explain the cross-section of earnings volatility, such as competition, earnings smoothing, debt- and equitymarket development, and firm size. Philippon (2002) suggests that product market competition contributes to volatile firm markups and thus to higher volatility in firm profits. To distinguish the effect of competition from the impact of governance mechanisms, we attempt to control for competition. We use a Herfindahl index, defined as the sum of the squared shares of firm sales to total sales within a given country, averaged for the period 1992-2002, $H_{c}=\frac{1}{T} \sum_{t} \sum_{i}\left(\frac{s_{i, c, t}}{\sum s_{j, c, t}}\right)^{2}$, where $s_{j, c, t}$ is the sales of company $j$ from country $c$ in fiscal year $t$. 


\section{Earnings smoothing}

Our second concern is that, as indicated earlier, our risk-taking measures may be influenced not only by the fundamental volatility of the investment projects but also by earnings smoothing incentives. Leuz et al. (2003) suggest that earnings management is used to conceal firm performance from outsiders, and argue that strong protection for investors limits private benefits of control and thus reduces managerial incentives to mask firm performance. To control for earnings smoothing we use a measure in Leuz et al. (2003), the ratio of the standard deviation of operating income (OI) and the standard deviation of operating cash flow (where both variables are scaled with lagged total assets), $E S_{1}=\left[\sum_{t=1992}^{2002}\left(\frac{O I_{i, c, t}}{A_{i, c, t}}-\sum_{t=1992}^{2002} \frac{O I_{i, c, t}}{A_{i, c, t}}\right)^{2} / \sum_{t=1992}^{2002}\left(\frac{O I_{i, c, t}-A_{i c r u a l}}{A_{i, c, t, t}}-\sum_{t=1992}^{2002} \frac{O I_{i, c, t}-A_{i c c r u a l}}{A_{i, c, t, t}}\right)^{2}\right]^{0.5}$.

Leuz et al. (2003) interprets lower values of this measure as evidence of higher level of earnings smoothing. In other words, earnings smoothing is high when the standard deviation of reported earnings relative to the standard deviation of earnings free of accrual is low. To facilitate interpretation we change the sign to $\mathrm{ES}_{2}=1-\mathrm{ES}_{1}$ so that higher values indicate higher propensity for earnings smoothing. In the above, operating cash-flow is defined as operating income (Compustat Global item \#14) minus accruals, where accruals are calculated as $\operatorname{ACCRUALS}_{i, t, c}=\left(\Delta C A_{i, t}-\Delta C A S H_{i, t}\right)-\left(\Delta C L_{i, t}-\Delta S T D_{i, t}-\Delta T P_{i, t}\right)-D E P_{i, t}$, where CA is total current assets (\#75), CASH is cash or cash equivalents (\#60), CL is total current liabilities (\#104), STD is short-term debt (item \#94), TP is taxes payable (\#100), and DEP is depreciation expense (\#11); all from Compustat Global. The $i$ indexes the company in point. In regression (10) with dependent variable RISK1, $\mathrm{ES}_{2}$ is a firm level variable. When we conduct the regression using country-level dependent variables (RISK2 and RISK3), $\mathrm{ES}_{2}$ is the median of the firm level observations in each country. 


\section{$\underline{\text { Financial Development }}$}

We also control for equity and debt market development in the growth regressions (11) and (12). Acemoglu and Zilibotti (1997) argue that at early stages of development the degree of risk-sharing the economy can achieve is limited; hence undertaking risky investments is less desirable for risk-averse managers whose human capital is under-diversified. As financial markets develop, risk avoidance diminishes since risk sharing is more readily achievable. Capital market development plays a crucial role in the reallocation of capital too: countries with developed financial markets may swiftly shift resources from declining industries to growing ones (Wurgler (2000)) and in the process generate volatility in the corporate cashflow stream. To control for financial development we use the 1991 stock market capitalization and the private domestic credit and non-financial domestic credit (as shares of the GDP) from Demirguç-Kunt and Levine (2001).

\section{Other controls}

In the growth regressions (11) and (12) we further incorporate standard controls, including real per-capita GDP, financial market development and human capital accumulation proxy (the average number of years of schooling as of 1990 from Barro and Lee (1993)). Since our growth regressions time window is from 1992 to 2002, these variables are measured at pre1992 values.

Finally, our various risk-taking measures are aimed to capture inherent risks in firm-level operations. However, the volatility measures are undoubtedly affected by macro-volatility. We consider two steps to address this. First, our volatility measures are based on the deviation of accounting returns from market averages. Second, to set aside major macro-volatility shocks 
(e.g., financial crises) that may impact our results, we exclude well-documented macroeconomic shocks from our data as follows: Argentina (1997 and 2001), Brazil (1997), Colombia (1997), Hong Kong (1997), Indonesia (1998, 1999), Malaysia (1997), Singapore (1997), Korea (1997), Thailand (1997 and 1998), and Turkey (2000 and 2001) (Li et al. (2004)).

\section{B. Data summary and univariate results}

Table 2 reports descriptive statistics for the main variables at the country level. The sample is chosen based on the requirement that data are available to compute the risk scores above. That leaves us with a sample of thirty-eight countries. The sample of firms included per countries varies from 13 firms (Columbia) to 1,818 (United States). ${ }^{10}$ Table 3 reports the pair-wise country correlations among the main variables. The correlation between the two country risktaking variables, RISK2 $\left(\sigma_{c}\right)$ and RISK3 $\left(\Omega_{c}\right)$ is $36 \%$, and is statistically significant. As discussed above, we deliberately create the $\Omega_{c}$ measure to be different from $\sigma_{c}$ because we are concerned about the representativeness of $\sigma_{c}$ as fundamental "risk-taking." The significant and positive correlation between the two is indicative that fundamental risk-taking may indeed be the driving force in both. We further notice that the index of earnings smoothing is negatively associated with RISK2. Thus, the skepticism that high volatility of firm level accounting returns may be partly due to low earnings smoothing is substantiated.

Both country-level measures of risk-taking are positively correlated with the three corporate accountability variables: the quality of accounting standards (ASR), the rule of law $(R L)$, and anti-director rights $(A D R)$. Of these, the correlations of RISK2 $\left(\sigma_{c}\right)$ with ASR (51\%) and with $A D R(27 \%)$ are statistically significant while the correlation of RISK2 with $R L$ is not.

\footnotetext{
${ }^{10}$ Rajan and Zingales (1995) discuss at length the reporting bias present in Compustat Global Vantage. See
} robustness checks section for further discussion. 
At the same time, the correlations of RISK3 $\left(\Omega_{c}\right)$ with ASR (49\%) and $R L(36 \%)$ are significant, however, its correlation with $A D R$ is not. These univariate results provide some support for our first hypothesis. Figures 1 through 3 show these correlations, which are visibly positive.

Economies with less competitive intensity, as judged by a higher Herfindahl index, tend to score lower on our risk-taking measures (the correlation coefficients are - $10 \%$ for RISK2 and $41 \%$ for RISK3, the latter of which is statistically significant). This appears consistent with the conjecture that intense competition increases the volatility of earnings (Philippon (2002)).

Finally, both country-level risk-taking measures are positively correlated with growth in real per-capita GDP and in total factor productivity. The scattered plots are shown in Figures 4 and 5. However, the correlations are not statistically significant. Either the hypothesized relationship does not exist, or perhaps the correlation omits variable important for growth.

\section{Multivariate results}

\section{A. Firm level tests}

We present our multivariate results in Tables 4 and 5, corresponding to firm-level and country-level tests. We start by examining the firm level results (Table 4). In Panel A we present the determinants of the firm-level risk-taking proxy (RISK1). We include anti-director rights $(A D R)$, accounting disclosure standards $(A S R)$, the rule of law $(R L)$, earnings smoothing, firm size, country level competition intensity ("country Herfindahl index") and proxies for financial development. Also included are 3-digit SIC code industry fixed effects. ${ }^{11}$ The regression results are consistent with our first hypothesis - the corporate accountability measures all have a

\footnotetext{
${ }^{11}$ In the firm level regression, we could model the error terms as showing industry fixed effects or random effects. The Hausman specification test statistics is 84.86 and thus rejects the null hypothesis of the existence of random effects.
} 
positive and statistically significant relation with firm-level risk-taking. They are significant whether entered individually or together.

Certain other variables also behave generally as expected. The earnings smoothing proxy attracts a negative coefficient, indicating that higher earnings smoothing is associated with lower volatility of accounting returns. Higher firm concentration, which we interpret as lower competitive intensity, is associated with lower volatility of accounting returns.

Our last control variables, the claims on the private sector by financial institutions and the stock market capitalization (both as shares of GDP) are more surprising. Their negative regression coefficients may reflect that in countries with high levels of loan financing, firms undertake less risky investments because that is what lenders prefer (Morck and Nakamura (2000)). Still that would not explain the negative coefficient on the equity market capitalization. Another possibility is that we have high collinearity - the capital market development measures are all highly correlated with accounting disclosure standards (ASR), the rule of law $(R L)$, and anti-director rights $(A D R)$. We observe negative signs on equity market capitalization in firm growth regressions in Panel B as well. While these results are problematic, the previous literature has reported similar results. ${ }^{12}$

Using model (4) in Table 4 Panel A, we compute the economic significance of the estimated coefficients. All three investor protection variables are highly statistically significant. Of the three, the one with most economic impact is anti-director rights $(A D R)$. A one standard deviation increase in $A D R$ is associated with an increase in the risk-taking proxy by $10.31 \%$ of its mean. A one standard deviation increase in the rule of law index $(R L)$ increases the risk-

\footnotetext{
${ }^{12}$ For example, Beck and Levine (2002) find results similar to ours: when both judicial efficiency (which is highly correlated with investor protection) and financial development are included as explanatory variables for industry growth across countries, only the former is significant and positive while the latter is negative and insignificant. Similarly, Demirguç-Kunt and Maksimovic (1998) show that in regressions of excess firm growth, the coefficient on the equity market size as a fraction of GDP is negative and insignificant.
} 
taking proxy by $9.73 \%$ of its mean. Of the three indicators, disclosure is the least statistically significant. A one standard deviation increase of disclosure increases the risk-taking proxy by $7.57 \%$ of its mean. Finally, among the control variables, a one standard deviation increase in the earnings smoothing measure decreases the risk-taking proxy by $12.72 \%$ of its mean.

In Table 4 panel B we relate two measures of firm-level growth, growth in total book value of assets and growth in sales, to the company level risk-taking proxy, $\sigma_{i, c}$. Both asset and sales growth are winsorized at the $0.5 \%$ level in both tails of the distribution. The regression controls for the three measures of investor protection, as well as for firm size and financial market development. For both growth variables, the regression coefficient for the risk-taking proxy is positive and statistically significant. The regressions are performed with industry fixed effects and control for firm size, credit market size, and stock market size.

The specifications in columns 2 and 5 could be problematic. In the first place, we include the investor protection variables because the law and finance literature advocates that better investor protections facilitate financing and thus firm growth (La Porta et al. (1997, 2002), Shleifer and Wolfenzon (2002)). Yet, we should note that the risk-taking measures are constructed proxies for the real risks in operations; and as such they are bound to have noise. Because of the noise, they may even be more inferior proxies for real risks in operations than the investor protection variables. Hence, observing that our risk-taking proxies do not significantly explain growth in the presence of investor protection proxies does not necessarily imply that risk-taking has no relationship with growth. It could reflect that our risk taking proxy contains a great deal of measurement error. Indeed, the ability of our risk-taking proxies to explain growth is reduced when the investor protection variables are included in the regressions: the risk-taking 
proxies are significant in all specifications, by more so in (1) and (4) than in (2) and (5) where the investor protection controls are included.

One way to tackle the issue is to instrument for the risk-taking proxy, and compare the predictive power of the regression that includes the instrumented risk-taking proxy, (models (3) and (6)) with the explanatory power of the regression with the investor protection variables only. ${ }^{13}$ We obtained the predicted risk-taking proxy as

$$
\bar{\sigma}_{i, c}=E\left(\sigma_{i, c} \mid A D R, A S R, R L\right) .
$$

We start by comparing models 2 and 3. Notice that the F-statistic is higher for model 3 as compared to model 2; a similar comparisons holds for the models 5 and 6 . Based on the Bayes information criterion (BIC), model 3 performs equally well as model 2. However, model 6 performs slightly better than model 5 based on BIC. These results indicate that models 3 and 6 perform at least as well as models 2 and $5 .{ }^{14}$

Using model 3 a one standard deviation increase in the instrumented volatility is associated with an increase in the asset growth of $61.9 \%$ (the figure using model 2 is $8.91 \%$ ). Similarly, based on model 6 a one standard deviation in the instrumented volatility proxy above its mean would increase the sales growth with $65.10 \%$ (the figure using model 5 is $13.07 \%$ ) $^{15}$.

\section{B. Country-level tests}

\footnotetext{
${ }^{13} \mathrm{We}$ include only the predicted risk-taking variable and do not include the investor protection institutional variables in the growth regressions (3) and (6) the former and latter are collinear by definition.

${ }^{14}$ In unreported results we have also compared the explanatory power of models 3 and 6 to models that include only the investor protection and control variables. These comparisons suggest that models 3 and 6 are the more parsimonious than models 2 and 5 .

${ }^{15}$ The controls reveal that larger firms have higher sales and assets growth. Firms from countries with more developed debt and equity markets have slower sales and asset growth. As discussed previously, even though we can not explain these latter results, we note that they mimic those in Beck and Levine (2002) and Demirguç-Kunt and Maksimovic (1998).
} 
A concern in the firm-level results is that more weight is given to countries with more firm-level observations. These are likely more advanced economies with better corporate governance foundations. A conservative approach is to give each country an equal weight by using only country level average of the firm level observations; that is, use RISK2 instead of RISK1. Such an approach sacrifices information but avoids over-weighting large economies. Results of the analysis are presented in Table 5.

Panel A reports regressions of our country level risk-taking proxy (RISK2) on disclosure, the rule of law, and anti-director rights. Model 1 reveals that disclosure is significantly positive. The rule of law coefficient is positive but only weakly significant, as shown in model 2 . The anti-director rights variable is even weaker. When all three institutional variables are included, only the disclosure variable attracts a significant regression coefficient, although the three variables are jointly significant. Thus, the more conservative approach of RISK2 generates results that broadly support the prediction that better investor protection increases risk-taking propensity.

In terms of economic significance (based on model 4) a one standard deviation increase in disclosure increases the risk-taking proxy by $16.92 \%$ of its mean. A one standard deviation increase in the rule of law increases the risk-taking proxy by $18 \%$ of its mean. A one standard deviation increase in anti-director rights increases the risk-taking proxy by $5.3 \%$ of its mean.

Panels $\mathrm{B}$ and $\mathrm{C}$ report the relationship between our country level risk-taking proxy and country growth. Model 2 in Panel B includes the risk-taking proxy and the investor protection variables in the same regression, in which case the explanatory power of the risk-taking proxy diminishes. As discussed above, this could indicate either that our hypothesis is not supported, or that our risk-taking proxy is (i) too closely correlated with the institutional variables and (ii) 
too noisy to compete with them. We therefore also report model 3 using the projection of our risk-taking proxy on the institutional variables, $\bar{\sigma}_{c}\left[\bar{\sigma}_{c}=E\left(\sigma_{c} \mid A D R, A S R, R L\right)\right]$ to represent risk-taking, as we did in the firm-level regressions. The predicted level of risk-taking $\bar{\sigma}_{c}$, attracts a positive and weakly significant coefficient in the full sample regression. Still, based on a comparison of the Bayes Information Criterion (BIC) for the two models, model 3 does not perform better than model 1 , in which the investor protection variables are used instead of $\bar{\sigma}_{c}$. Thus, these results do not provide significant support to the proposition that high risk-taking contributes to per-capita real GDP growth.

Panel $\mathrm{C}$ of Table 5 reports regressions using total factor productivity as the dependent variable. The regression specifications are otherwise identical to those in table 5 panel B. Here, the predicted risk-taking measure $\left(\bar{\sigma}_{c}\right)$ now out-performs regressions that replace variables with the original investor protection variables. The results indicate statistical significance on the instrumented risk-taking proxy. Note also that in comparing model 3 to models 1 and 2 , the model using the predicted risk-taking measure produce marginally better AIC, BIC and Fstatistics. We interpret these as support for the hypothesis that our risk-taking measures are associated with higher productivity growth.

\section{Multivariate results using RISK3 measure}

The above results in $B$, some of which are statistically weak, may reflect the fact that our country-level risk-taking proxy (RISK2) is noisy. It certainly is affected by earnings management given its inverse relationship to income-smoothing. This concern motivates the third risk-taking measure RISK3 $\left(\Omega_{c}\right)$, which is an industry value-weighted average of risktaking measures using US data. As argued above, RISK3 may be subject to less earnings 
management since it utilizes data from the country with relatively modest earnings smoothing. The right panel of Table 5A reports regressions using RISK3 as a dependent variable. Among all the investor protection institutional variables, the strongest determinant of imputed risk-taking is the accounting disclosure variable. It is positive and highly significant in all specifications. Based on model 5 in Table 5 panel A, a one standard deviation increase in disclosure increases the risk-taking proxy by $8.62 \%$ of its mean. Both anti-director rights and rule of law indicators are insignificant, the latter even has the opposite sign. Still, these results fit our theoretical results because disclosure is the institutional environmental variable that most directly captures the likelihood of discovering managerial stealing; the anti-director and the rule of law variables are indirect measures of what we intend to capture.

Table 5B model 4 is the regression of real per-capita GDP growth on RISK3 $\left(\Omega_{c}\right)$, and on the institutional environment variables, controlling for various initial conditions. We also show, in model 5 the results for the projected RISK3 $\left(\bar{\Omega}_{c}\right)$ defined as

$$
\bar{\Omega}_{c}=E\left(\Omega_{c} \mid A S R, R L, A D R\right)
$$

Model 5 shows that the coefficient on $\bar{\Omega}_{c}$ is positive and significant. That model is marginally more parsimonious than model 4 , as measured by the AIC and BIC, where the investor protection variables are directly entered. Based on model 5 a one standard deviation increase of $\bar{\Omega}_{c}$ is associated with a $32.68 \%$ increase in real GDP-per-capita growth from its mean.

Model 4 in Table 5 panel $\mathrm{C}$ is the regression of productivity growth measures on RISK3 $\left(\Omega_{c}\right)$ and on the institutional environment variables. Model 5 is the regression on the projected 
RIK3 $\left(\bar{\Omega}_{c}\right)$. We observe that $\bar{\Omega}_{c}$ attracts a positive and statistically significant coefficient. Also, in comparing the specifications that using the projected risks measure $\bar{\Omega}_{c}$ and the investor protection variables directly (model 4), we find that the former is marginally more parsimonious than the latter in terms of AIC and BIC statistics. Based on model 5 a one standard deviation increase of $\bar{\Omega}_{c}$ is associated with a $45.73 \%$ increase of the TFP growth above its mean. Overall, we have shown limited evidence that there exists a positive association between risk-taking and investor protection and a positive association between risk-taking and growth. We now offer more robustness checks on these results.

\section{Robustness Checks}

A drawback of the Compustat Global Vantage is its limited firm coverage (Rajan and Zingales (1995)). Firms that are selected to be included in this database are likely the ones that are attractive to global investors and are able to overcome their home countries' investor protection problems. This selection bias reduces the dependence of firm-level governance on country-level institutions and would tend to work against our hypotheses. Yet, we find affirmative evidence for our hypotheses. Home-country institutions seem to remain the dominant factor in corporate governance (Doidge et al. (2004)).

Finally, including firms that have cross-listed their stock may weaken our results since their governance is likely less affected by the host country institutional environment. To investigate these issues, we repeat our regressions from Table 4 Panels A and B but restrict our sample to non-cross-listed firms. We obtained stronger results (available upon request).

\section{Conclusions}


In this paper we consider the relationship between investor protection and risk-taking by perk-consuming managers. In our model, managers choose their optimal level of perk consumption taking into account the degree of investor protection in place in the embedding economy. Since perks represent a priority claim held by the managers, larger perks align their incentives more closely with these of debt holders in their choice of investment risk - with the implication that managers may skip risky but value-enhancing projects to protect their perk consumption. Better investor protection, on the other hand, lowers the optimal level of perks, causing managers to be less risk-averse and better aligned with shareholders in their investment risk choices. The basic predictions are that managers residing in better-protected investor regimes will take on more value-enhancing risks and achieve faster firm growth.

We test the implications of our model in an unbalanced panel of manufacturing companies from thirty-eight countries from the Compustat Global Vantage covering 1992-2002. Consistent with theoretical predictions, we document significant positive relationships between various firm- and country- level risk-taking measures and measures of corporate accountability, and also between risk-taking and growth. Our results are generally robust to controls for firm earnings management, competition in the local economy, financial market development, and general economic development.

We believe that this study contributes to the broader literatures on investor protection and growth in several important ways. First, we provide a novel explanation for why better investor protection leads to faster growth. Second, our study is the first to empirically document an impact of risk-taking on growth. We hope that future research on investor protection and growth will shed further light o this potentially. 


\section{References}

Acemoglu, D., F. Zilibotti, 1997, "Was Prometheus Unbound by Chance? Risk, Diversification, and Growth," Journal of Political Economy, Vol. 105: 709-751.

Allen, F., D. Gale, 1997, "Financial Markets, Intermediaries, and Intertemporal Smoothing," Journal of Political Economy, Vol. 105: 523-546.

Allen, F., D. Gale, 2000, “Corporate Governance and Competition”, Corporate Governance: Theoretical and Empirical Perspectives, edited by X. Vives, Cambridge University Press, 23-94.

Ball, R., S. P. Kothari, A. Robin, 2000, "The Effect of International Institutional Factors on Properties of Accounting Earnings", Journal of Accounting and Economics, Vol. 29: 1-51.

Barro, R., J.W. Lee, 1993, "International Comparisons of Educational Attainment," Journal of Monetary Economics, Vol. 32: 363-394.

Beck, T., R. Levine, 2002, "Industry Growth and Capital Allocation: Does Having a Market- or Bankbased System Matter?" Journal of Financial Economics, Vol. 64: 147-180.

Beck, T., A. Demirguç-Kunt, R. Levine, 2003, "Law, Endowments, and Finance," Journal of Financial Economics, Vol. 70: 137-181.

Bhattacharya, U., H. Daouk, M. Welker, 2003, “The World Price of Earnings Opacity,” The Accounting Review, Vol. 78: 641-678.

Demirguç-Kunt, A., V. Maksimovic, 1998, "Law, Finance, and Firm Growth," Journal of Finance, Vol. 53: 2107-2137.

Demirguç-Kunt, A., R. Levine (Eds.), 2001, "Financial Structure and Economic Growth: Cross-Country Comparisons of Banks, Markets, and Development", MIT Press, Cambridge, MA.

Doidge, C., A. Karolyi, R. Stulz, 2004, "Why do Countries Matter So Much More for Corporate Governance?" working paper, Ohio State University.

Durnev, A., K. Li, R. Morck, B. Yeung, 2004, "Capital Markets and Capital Allocation: Implications for Economies in Transition," Economics of Transition, forthcoming.

Durnev, A., , R. Morck, B. Yeung, 2004, "Value Enhancing Capital Budgeting and Firm-Specific Stock Returns Variation," Journal of Finance, Vol. 59.

Fisman, R., I. Love, 2003, "Trade Credit, Financial Intermediary Development, and Industry Growth", Journal of Finance, Vol. 58: 353-374.

Greene, W., 2002, Econometric Analysis, Fifth Edition, Prentice Hall.

Himmelberg, C., R. Glenn Hubbard, I. Love, 2002, "Investor Protection, Ownership, and the Cost of Capital," working paper, Columbia University.

Hirshleifer, D., and A. Thakor, 1992, "Managerial Conservatism, Project Choice, and Debt,” The Review of Financial Studies, Vol. 5: 437-470.

Holmstrom, B. J. Ricart I Costa, 1986, “Managerial Incentives and Capital Management,” The Quarterly Journal of Economics, Vol. 101: 835-860. 
Jensen, M., W. Meckling, 1976, "Theory of the firm: Managerial behavior, agency costs and ownership structure," Journal of Financial Economics, Vol. 3: 305-360.

John, T., K. John, 1993, “Top-Management Compensation and Capital Structure,” Journal of Finance, Vol. 48: 949-974.

King, R., R. Levine, 1993a, "Finance and Growth: Schumpeter Might be Right," Quarterly Journal of Economics, Vol. 108: 717-738.

King, R., R. Levine, 1993b, "Finance, Entrepreneurship, and Growth: Theory and Evidence," Journal of Monetary Economics, Vol. 32: 513-542.

La Porta, R., F. Lopez-de-Silanes, A. Shleifer, R. Vishny, 1997, "Legal Determinants of External Finance," Journal of Finance, Vol. 52: 1131-1150.

La Porta, R., F. Lopez-de-Silanes, A. Shleifer, R. Vishny, 1998, “Law and Finance,” Journal of Political Economy, Vol. 106: 1113-1155.

La Porta, R., F. Lopez-de-Silanes, A. Shleifer, R. Vishny, 2002, "Investor Protection and Corporate Valuation," Journal of Finance, Vol. 57: 1147-1170.

Levine, R., 1997, "Financial Development and Economic Growth: Views and Agenda", Journal of Economic Literature, Vol. 35: 688-726.

Leuz, C., D. Nanda, P. Wysocki, 2003, "Earnings Management and Investor Protection: an International Comparison," Journal of Financial Economics, Vol. 69: 506-527.

Li, K., R. Morck, F. Yang, B. Yeung, 2004, "Firm-Specific Variation and Openness in Emerging Markets," Review of Economics and Statistics, Vol. 86: 658-669.

Morck R., M. Nakamura, 1999, "Banks and Corporate Control in Japan”, Journal of Finance, Vol. 54: 319-339.

Philippon, T., 2002, “Corporate Governance and Aggregate Volatility,” working paper, MIT.

Rajan, R., L. Zingales, 1995, "What Do We Know About Capital Structure? Some Evidence From International Data," Journal of Finance, Vol. 50: 1421-1460.

Rajan, R., L. Zingales, 1998, "Financial Development and Growth", American Economic Review, Vol. 88: 559-586.

Shleifer, A., D. Wolfenzon, 2002, "Investor Protection and Equity Markets," Journal of Financial Economics, Vol. 66: 3-27.

Siegel, J., 2004, "Can Foreign Firms Bond Themselves Effectively by Renting U.S. Securities Laws?" Journal of Financial Economics, forthcoming.

Wachtel, P., 2003, “How Much Do We Know About Growth and Finance?” Economic Review, Federal Reserve Bank of Atlanta, First Quarter Vol.: 33-47.

Wurgler, J., 2000, "Financial Markets and the Allocation of Capital," Journal of Financial Economics, Vol. 58: 187-214. 
Zingales, L., 2003, “Commentary,” Economic Review, Federal Reserve Bank of St. Luis, July/August Vol.: 1-6. 


\section{Appendix.}

Proof of proposition 2. We consider three cases.

Case 1: "Low" perk consumption, $L>\frac{(1-\phi)^{2} g^{2}}{4 \alpha^{2}}$. The first order condition is $\widetilde{q}\left\{\alpha H+\frac{(1-\phi)^{2} g^{2}}{4 \alpha}\right\}+(1-\widetilde{q})\left\{\alpha L+\frac{(1-\phi)^{2} g^{2}}{4 \alpha}\right\}=\left\{\alpha I+\frac{(1-\phi)^{2} g^{2}}{4 \alpha}\right\}$. Thus, $\widetilde{q}=\frac{I-L}{H-L}=\bar{q}$; there is no investment distortion.

Case 2: "Medium" perk consumption, $I>\frac{(1-\phi)^{2} g^{2}}{4 \alpha^{2}} \geq L$. The first order condition is $\widetilde{q}\left\{\alpha H+\frac{(1-\phi)^{2} g^{2}}{4 \alpha}\right\}+(1-\widetilde{q})\{(1-\phi) g \sqrt{L}\}=\left\{\alpha I+\frac{(1-\phi)^{2} g^{2}}{4 \alpha}\right\}$.

Then

$\widetilde{q}=\frac{\alpha I+\frac{(1-\phi)^{2} g^{2}}{4 \alpha}-(1-\phi) g \sqrt{L}}{\alpha H+\frac{(1-\phi)^{2} g^{2}}{4 \alpha}-(1-\phi) g \sqrt{L}}=\frac{I-L+A}{H-L+A}$

where $A=L-\frac{(1-\phi) g}{\alpha} \sqrt{L}+\frac{(1-\phi)^{2} g^{2}}{4 \alpha^{2}}=\left(\sqrt{L}-\frac{(1-\phi) g}{2 \alpha}\right)^{2} \geq 0 . \quad$ It $\quad$ follows $\quad$ that $\quad \widetilde{q} \geq \bar{q}$ since $\frac{I-L+A}{H-L+A} \geq \frac{I-L}{H-L}$.

Case 3: "High" perk consumption, $H>\frac{(1-\phi)^{2} g^{2}}{4 \alpha^{2}} \geq I$. The first order condition is $\widetilde{q}\left\{\alpha H+\frac{(1-\phi)^{2} g^{2}}{4 \alpha}\right\}+(1-\widetilde{q})\{(1-\phi) g \sqrt{L}\}=(1-\phi) g \sqrt{I}$. $\quad$ The investment $\quad$ policy is $\widetilde{q}=\frac{(1-\phi) g(\sqrt{I}-\sqrt{L})}{\alpha H+\frac{(1-\phi)^{2} g^{2}}{4 \alpha}-(1-\phi) g \sqrt{L}}$. We will show $\widetilde{q} \geq \bar{q}$ i.e. $\frac{(1-\phi) g(\sqrt{I}-\sqrt{L})}{\alpha H+\frac{(1-\phi)^{2} g^{2}}{4 \alpha}-(1-\phi) g \sqrt{L}} \geq \frac{I-L}{H-L} \cdot$ We can re-write this inequality as a polynomial in $x=\frac{(1-\phi) g}{2 \alpha}: f(x)=-x^{2}+2\left(\frac{H+\sqrt{I L}}{\sqrt{I}+\sqrt{L}}\right) x-H \geq 0$. Thus it suffices to show that $g(x) \geq 0$ for $x \in[\sqrt{I}, \sqrt{H})$. The roots of the polynomial $f(x)=0$ are $\frac{H+\sqrt{I L} \pm \sqrt{(H-I)(H-L)}}{\sqrt{I}+\sqrt{L}}$. We will show $[\sqrt{I}, \sqrt{H}) \subset\left(\frac{H+\sqrt{I L}-\sqrt{(H-I)(H-L)}}{\sqrt{I}+\sqrt{L}}, \frac{H+\sqrt{I L}+\sqrt{(H-I)(H-L)}}{\sqrt{I}+\sqrt{L}}\right)$. Indeed $\frac{H+\sqrt{I L}-\sqrt{(H-I)(H-L)}}{\sqrt{I}+\sqrt{L}}<\sqrt{I}$ and similarly $\sqrt{H}<\frac{H+\sqrt{I L}+\sqrt{(H-I)(H-L)}}{\sqrt{I}+\sqrt{L}}$. $\quad$ Q.E.D.

Proof of Proposition 3. We consider three cases.

Case 1: “Low" perk consumption, $L>\frac{(1-\phi)^{2} g^{2}}{4 \alpha^{2}}$. As shown above $\widetilde{q}=\frac{I-L}{H-L}=\bar{q}$ and $\frac{\partial \widetilde{q}}{\partial \phi}=0$.

Case 2: "Medium" perk consumption, $I>\frac{(1-\phi)^{2} g^{2}}{4 \alpha^{2}} \geq L$. As shown above, $\widetilde{q}=\frac{I-L+A}{H-L+A}$ with $A=\left(\sqrt{L}-\frac{(1-\phi) g}{2 \alpha}\right)^{2} \geq 0$. Simple derivation show that $\frac{\partial \widetilde{q}}{\partial A}>0$ and $\frac{\partial A}{\partial \phi}<0$. 
Case 3: "High" perk consumption, $H>\frac{(1-\phi)^{2} g^{2}}{4 \alpha^{2}} \geq I$. Notice that $\frac{(\sqrt{I}-\sqrt{L})}{\widetilde{q}=\frac{\alpha H}{\frac{(1-\phi) g}{(1-\phi)} g-\sqrt{L}}}$. Further, $\frac{\partial\left(\frac{\alpha H}{(1-\phi) g}+\frac{(1-\phi)}{4 \alpha} g-\sqrt{L}\right)}{\partial(1-\phi)}=-\frac{\alpha H}{(1-\phi)^{2} g}+\frac{g}{4 \alpha}<0 \quad$ (by assumption) $\quad$ which $\quad$ implies $\quad \frac{\partial \widetilde{q}}{\partial(1-\phi)}>0 \quad$ i.e. $\quad \frac{\partial \widetilde{q}}{\partial \phi}<0$.

Q.E.D.

Optimal Compensation. In this section we address the optimality of the incentives given to the manager, $\alpha$. In equilibrium, incentives will be set to equate the first best investment policy, $\bar{q}$, to the second best one, $\widetilde{q}$. Since the discussed investment distortion arises when $(1-\phi)^{2} g^{2} / 4 \alpha^{2} \geq L$, the optimal incentives solve $\widetilde{q}=\bar{q}$. We substitute for both and force ${ }^{16}$ $\frac{I-L+A}{H-L+A}=\frac{I-L}{H-L}$, where $A=\left(\sqrt{L}-\frac{(1-\phi) g}{2 \alpha}\right)^{2}$. The solution to the above is $\mathrm{A}=0$, or $\alpha_{L}=(1-\phi) / 2 \sqrt{L}$. Under this incentive scheme the manager would receive the same level of perks in any state of the world, $L=(1-\phi)^{2} g^{2} / 4 \alpha^{2}$, regardless of her project choice. However, if $\phi$ is sufficiently low in a sense to become clear below, it might not be possible to award the manager such incentives. Providing high-powered incentives (which in our model take the form of ownership stake), e.g. the entire cashflow, $\alpha=1$, when $\phi=0$, would effectively require the manager to buy a large fraction of the firm. Since the manager might be wealth-constrained, the maximum share of the entire firm that could be given to her could only be $\alpha_{W}=\frac{W}{V}$, where $W$ is the wealth of the manager and $V$ is the rationally anticipated value of the firm. Thus, in equilibrium, the optimal amount of incentives is given by $\alpha^{*}=\min \left\{\alpha_{L}, \alpha_{W}\right\}$. Thus if $\alpha_{W}<\alpha_{L}$, there will be a set of $\alpha^{*}$, such that $(1-\phi)^{2} g^{2} / 4 \alpha^{2}>L$ over which $\frac{\partial \widetilde{q}}{\partial \phi}<0$. In our framework so far the manager is assumed to be risk-averse in her perk consumption. However, if she is assumed to be risk averse in her contracted compensation too, high levels of incentives could also have an impact on her choice of risk. The hedging demands due to risk-aversion in her preferences would lead to an optimal level of incentives, $\alpha_{R}$. Therefore the optimal ownership stake is given by $\alpha^{*}=\min \left\{\alpha_{L}, \alpha_{R}, \alpha_{W}\right\}$. Notice that if $\alpha_{W}<\alpha_{L}$ or $\alpha_{W}<\alpha_{R}, \alpha^{*}=\alpha_{W}$. In this case all our results

\footnotetext{
${ }^{16}$ Notice we equate $\widetilde{q}$ from case (b) in Proposition 2 to $\bar{q}$. Finding an optimal $\alpha$ that equates $\widetilde{q}$ to $\bar{q}$ effectively eliminates the distortion that arises in case (c) of Proposition (2) as well.
} 
continue to hold for the endogenously determined value of $\alpha$ where the binding constraint on $\alpha$ is determined by the wealth constraint of the manager, and we replace $\alpha$ by $\alpha_{W}$ in all these results. 
Table 1. Variable Definitions.

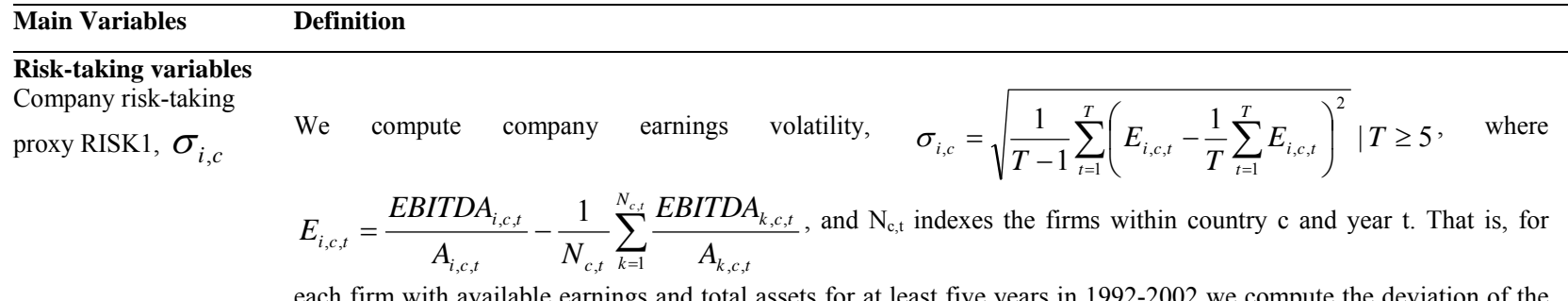

each firm with available earnings and total assets for at least five years in 1992-2002 we compute the deviation of the firm's EBITDA/Assets from the country average (for the corresponding year) and then calculate the standard deviation of this measure for each firm. $E_{i, c, t}$ is winsorized at $0.5 \%$ on both sides of the sample distribution to account for data entry omissions.

Country risk-taking proxy RISK2, $\sigma_{c}$ Imputed risk score RISK3, $\Omega_{c}$
The average of the company risk-taking proxy (RISK1), $\sigma_{c}=\frac{1}{N_{c}} \sum_{i=1}^{N_{c}} \sigma_{i, c} \mid N_{c} \geq 2$.

Calculated for each country over the period 1992-2002. The imputed risk scores are obtained using the following formula, $\Omega_{c}=\frac{1}{11} \sum_{t=1992}^{t=2002}\left(\sum_{j \in\{200, \ldots, 399\}} M V_{t, j, c} \times \sigma^{U S A}{ }_{1994-1997, j} / \sum_{j \in\{200, \ldots, 399\}} M V_{t, j, c}\right)$, where $j$ is an industry subscript based on 3-digit SIC codes, $c$ is a country subscript, $t$ is a year subscript, $M V_{t, j, c}$ is the market capitalization in industry $j$ in year $t$ for country $c$, and $\sigma_{1994-1997, j}^{U S A}$ is the industry $j$ risk score computed using only US single business segment firms for the period 1994-1997. In the computation of $\sigma_{1994-1997, j}^{\text {USA }}$ we include firm-years where sales are above 10 million US\$. Market values (MV) are computed as of the end of the fiscal year. Prices and shares outstanding data is compiled from Global Vantage Issue database. The $\sigma_{1994-1997, j}^{\text {USA }}$ is computed as the withinindustry variation of $E_{i, j, t}^{U S A}=\left(E B I T D A_{i, j, t}^{U S A} / A_{i, j, t}^{U S A}\right)-\frac{1}{N^{U S A}} \sum_{j} \sum_{i=1}^{N_{j}}\left(E B I T D A_{i, j, t}^{U S A} / A_{i, j, t}^{U S A}\right)$ i.e.

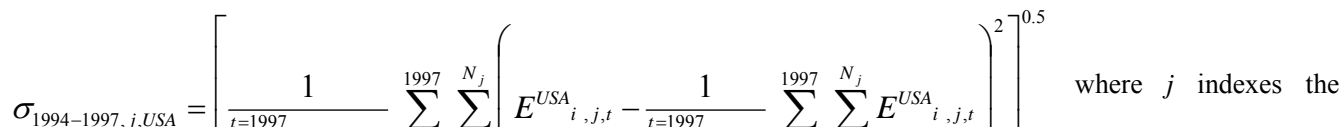
$\sigma_{1994-1997, j, \text { USA }}=\left[\frac{1}{\sum_{t=1994}^{t=1997} N_{j, t}^{U S A}-1} \sum_{t=1994} \sum_{i=1}\left(E_{i, j, t}^{U S A}-\frac{1}{\sum_{t=1994}^{t=1997} N_{j, t}^{U S A}} \sum_{t=1994} \sum_{i=1} E_{i, j, t}^{U S A}\right]\right.$

manufacturing industries defined as 3-digit SIC codes and $i$ indexes the companies within a given industry. Prior to computing $\sigma_{1994-1997, j}^{U S A}$ we winsorize $E_{i, j, t}^{U S A}$ at $0.5 \%$ on both sides of its distribution to account for data entry omissions. The single business segment firms are identified from the Compustat Segment file. EBITDA corresponds to data item \#13 (Operating Income Before Depreciation) and A refers to data item \#6 (Total Assets), both from Compustat North America, for the period 1994-1997. We start in 1994 to avoid the recession years preceding it. The sample ends in 1997 to account for the changed US practices of reporting business units as of 1997 (FAS 131 changed the rules of reporting segments, rendering comparisons of US segments pre- and post-1997 imprecise).

\section{Source}

Compustat Global Industrial/Commercial Annual Database.
Compustat Global Industrial/Commercial Annual Database.

Compustat Global Industrial/Commercial Annual Database and

Compustat North Americal Industrial Annual Database.

\section{Growth Variables}

Real-GDP-per capita growth

Total Factor Productivity growth
Growth rate of real per capita GDP. The latter is measured in 1995 constant US\$. The nominal GDP, GDP deflator and population data, used to compute it are obtained from the International Financial Statistics of the IMF. We use the line data item 99bvp and 99bvr that are presented on a reference year 1995 (GDP volume index assumed 100 in 1995) in the IFC yearbook.

To measure TFP we follow algorithm similar to King and Levine (1994). We use the recursion $K_{c, t+1}=K_{c, t}+I_{c, t}-\delta K_{c, t}$, where $\mathrm{c}$ indexes countries, $t$ is the time period, $\mathrm{K}$ is the real capital stock in year $\mathrm{t}$ and country c, I is the real capital investment in year $\mathrm{t}$ and country c, and $\delta$ is the rate of depreciation, which in accord with previous studies we assume to be the same across all countries, $7 \%$. We start the recursion by assuming that in 1950 (the beginning of the data by Penn World Tables version 6.1) the capital stock is 0. Iterating forward we obtain the capital stock for each year in 1992-2000 (the last date with available data in PWT). We then define capital stock per capita, $\mathrm{k}$, as the ratio of the real capital stock to the population. The productivity growth is finally defined as: $\Delta \ln (y)-0.3 \Delta \ln (k)$, where the capital stock intensity is assumed $30 \%$ across all countries.
International Financial Statistics of the International Monetary Fund.

Penn World Tables, version 6.1 . 
Average assets growth Average assets (line item \#89) growth over the sample period, 1992-2002. Prior to computing the growth we convert all accounting data in US\$. We have further winsorized the assets at the $0.5 \%$ level on both sides of the sample distribution.

Average sales growth Average sales (line item \#1) growth over the sample period, 1992-2002. Prior to computing the growth we convert all accounting data in US\$. We have further winsorized the sales at the $0.5 \%$ level on both sides of the sample distribution.

Investor Protection Variables

Rule of Law (RL) Rule of law is the assessment of the law and order tradition of the country. Calculated as "average of the months of April and October of the monthly index between 1982 and 1995. Scale from zero to 10, with lower scores for less tradition for law and order."

Rating of Accounting Standards (ASR)

Index that is created by "examining and rating companies' 1990 annual report on their inclusion or omission of 90 items. These items fall into seven categories (general information, income statements, balance sheets, fund flow statement, accounting standards, stock data, and special items). A minimum of three companies in each country were studied." Approximately $70 \%$ of the companies screened are industrials, while the remaining $30 \%$ represent financials.

Anti-director rights (ADR)
An index that aggregates shareholder rights. "The index is formed by adding one when: (1) the country allows shareholders to mail their proxy vote to the firm, (2) shareholders are not required to deposit their shares prior to the general shareholders' meeting, (3) cumulative voting or proportional representation of minorities in the board of directors is allowed, (4) an oppressed minorities mechanism is in place, (5) the minimum percentage of share capital that entitles a shareholder to call for an extraordinary shareholders' meeting is less than or equal to 10 percent (the sample median), or (6) shareholders have preemptive rights that can be waived only by a shareholders' vote. The index ranges from zero to six."
Compustat Global Industrial/Commercial Annual Database.

Compustat Global Industrial/Commercial Annual Database.

International Country Risk Guide; Quotation is from La Porta et al. (1998).

Center for

International

Financial Analysis and Research. Quotation is from La Porta et al. (1998) Quotation is from $\mathrm{La}$ Porta et al. (1998)

\section{Control Variables}

Earnings Smoothing

Herfindahl Index

Private Credit

Market Capitalization

Average Schooling

1991 \$ GDP-per-capita
A measure of earnings smoothing due to managerial incentives. Computed in Ball, Kothari, Robin (2000) and used also in Bhattacharya, Daouk, Welker (2002), and in Leuz, Nanda, Wysocki (2003). It is computed as the ratio of the firm level standard deviations of operating income (OI) and operating cash flow where both variables are scaled with lagged total assets,

$$
E S_{1}=\left[\sum_{t=1992}^{2002}\left(\frac{O I_{i, c, t}}{A_{i, c, t}}-\sum_{t=1992}^{2002} \frac{O I_{i, c, t}}{A_{i, c, t}}\right)^{2} / \sum_{t=1992}^{2002}\left(\frac{O I_{i, c, t}-\text { Accrual }_{i, c, t}}{A_{i, c, t}}-\sum_{t=1992}^{2002} \frac{O I_{i, c, t}-\text { Accrual }_{i, c, t}}{A_{i, c, t}}\right)^{2}\right]^{0.5} \cdot \text { The }
$$

higher the value of this measure, the lower earnings smoothing is. To facilitate interpretation, we thus consider the modified measure $E S_{2}=1-E S_{1}$, for which higher values indicate higher level of earnings smoothing. Operating cashflow is equal to operating income (Compustat Global item \#14) minus accruals, where accruals are calculated as $\operatorname{ACCRUALS}_{i, t, c}=\left(\Delta C A_{i, t}-\Delta C A S H_{i, t}\right)-\left(\Delta C L_{i, t}-\Delta S T D_{i, t}-\Delta T P_{i, t}\right)-D E P_{i, t}$, where CA is total current assets (item \#75), CASH is cash or cash equivalents (\#60), CLS is total current liabilities (\#104), and STD is short-term debt (item \#94), TP is taxes payable (\#100), and DEP is depreciation expense (\#11); I indexes the company in point. We compute the country analogous measure to the above one as the median firm ratio for each country.

To control for competition we use a Herfindahl index, defined as the sum of the squared shares of firm sales to total sales within a given country for the period 1992-2002, $H_{c}=\frac{1}{T} \sum_{t} \sum_{i}\left(\frac{s_{i, c, t}}{\sum s_{j, c, t}}\right)^{2}$, where $S_{j, c, t}$ is the sales of

company $j$ from country $c$ in fiscal year $t$.

Claims on private sector by deposit money banks and other financial institutions as share of GDP.

Stock market capitalization as share of GDP.

Average schooling years in the total population over 25 in 1990.

1991 GDP-per-capita in 1995 constant US dollar terms.
Compustat Global Industrial/Commercial Annual Database.

Compustat Global Industrial/Commercial Annual Database.

Beck, Demirguç-Kunt and Levine (2003)

Beck, Demirguç-Kunt and Levine (2003)

Barro and Lee (1993).

International

Financial Statistics of the International Monetary Fund. 
Table 2. Descriptive Statistics.

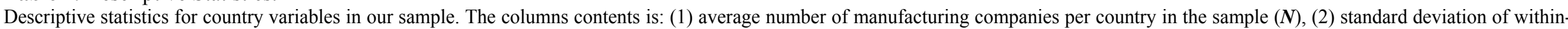

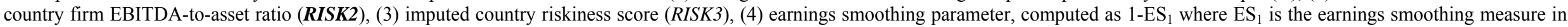

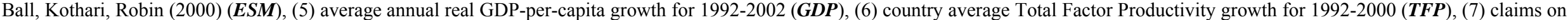

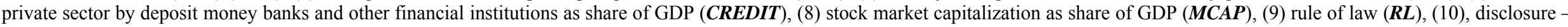

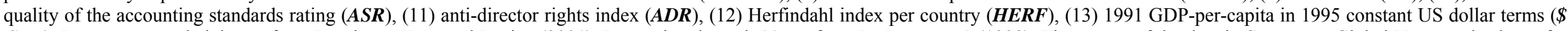

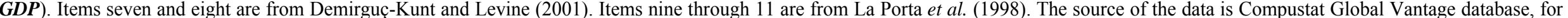

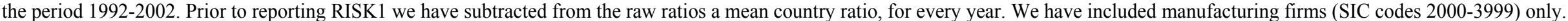

\begin{tabular}{|c|c|c|c|c|c|c|c|c|c|c|c|c|c|}
\hline \multirow[b]{3}{*}{ Country } & \multicolumn{13}{|c|}{ Variables } \\
\hline & (1) & (2) & (3) & (4) & (5) & (6) & (7) & (8) & (9) & (10) & (11) & (12) & (13) \\
\hline & $\mathbf{N}$ & RISK2 & RISK3 & ESM & GDP & TFP & CREDIT & MCAP & RL & ASR & ADR & HERF & \$ GDP \\
\hline Argentina & 15 & 0.062 & 0.128 & 0.35 & $-0.1 \%$ & $2.7 \%$ & 0.15 & 0.05 & 5.35 & 45 & 4 & 0.25 & $\$ 5,771$ \\
\hline Australia & 101 & 0.077 & 0.097 & 0.21 & $2.6 \%$ & $2.1 \%$ & 0.81 & 0.43 & 10 & 75 & 4 & 0.07 & $\$ 18,302$ \\
\hline Austria & 53 & 0.040 & 0.082 & 0.58 & $1.6 \%$ & $1.0 \%$ & 0.87 & 0.07 & 10 & 54 & 2 & 0.14 & $\$ 21,652$ \\
\hline Belgium & 54 & 0.041 & 0.088 & 0.50 & $2.3 \%$ & $1.1 \%$ & 0.37 & 0.26 & 10 & 61 & 0 & 0.14 & $\$ 20,320$ \\
\hline Brazil & 84 & 0.052 & 0.076 & 0.42 & $1.5 \%$ & $1.6 \%$ & 0.25 & 0.12 & 6.32 & 54 & 3 & 0.18 & $\$ 2,712$ \\
\hline Canada & 224 & 0.090 & 0.121 & 0.21 & $3.2 \%$ & $1.6 \%$ & 0.77 & 0.46 & 10 & 74 & 5 & 0.03 & $\$ 21,057$ \\
\hline Chile & 41 & 0.030 & 0.055 & 0.45 & $3.9 \%$ & $2.6 \%$ & 0.50 & 0.43 & 7.02 & 52 & 5 & 0.23 & $\$ 2,601$ \\
\hline Colombia & 13 & 0.022 & 0.093 & 0.39 & $0.6 \%$ & $-0.1 \%$ & 0.27 & 0.06 & 2.08 & 50 & 3 & 0.34 & $\$ 1,347$ \\
\hline Denmark & 73 & 0.050 & 0.158 & 0.33 & $2.0 \%$ & $1.6 \%$ & 0.42 & 0.22 & 10 & 62 & 2 & 0.07 & $\$ 26,035$ \\
\hline Finland & 64 & 0.047 & 0.147 & 0.30 & $2.4 \%$ & $2.7 \%$ & 0.67 & 0.18 & 10 & 77 & 3 & 0.09 & $\$ 24,627$ \\
\hline France & 264 & 0.044 & 0.117 & 0.40 & $1.4 \%$ & $0.9 \%$ & 0.91 & 0.20 & 8.98 & 69 & 3 & 0.05 & $\$ 20,923$ \\
\hline Germany & 313 & 0.060 & 0.115 & 0.50 & $1.1 \%$ & $0.3 \%$ & 0.92 & 0.19 & 9.23 & 62 & 1 & 0.05 & $\$ 22,135$ \\
\hline Greece & 25 & 0.033 & 0.052 & 0.41 & $2.4 \%$ & $2.5 \%$ & 0.40 & 0.08 & 6.18 & 55 & 2 & 0.24 & $\$ 8,813$ \\
\hline Hong Kong & 45 & 0.067 & 0.109 & 0.41 & $2.0 \%$ & $0.8 \%$ & 1.36 & 1.28 & 8.22 & 69 & 5 & 0.09 & $\$ 14,947$ \\
\hline India & 184 & 0.048 & 0.082 & 0.38 & $4.0 \%$ & $2.7 \%$ & 0.27 & 0.13 & 4.17 & 57 & 5 & 0.10 & $\$ 339$ \\
\hline Indonesia & 62 & 0.060 & 0.092 & 0.32 & $4.5 \%$ & $2.9 \%$ & 0.26 & 0.05 & 3.98 & - & 2 & 0.16 & $\$ 708$ \\
\hline Ireland & 22 & 0.047 & 0.135 & 0.21 & $6.4 \%$ & $5.3 \%$ & 0.63 & 0.27 & 7.8 & - & 4 & 0.14 & $\$ 13,546$ \\
\hline Israel & 25 & 0.062 & 0.075 & 0.32 & $1.1 \%$ & $0.9 \%$ & 0.51 & 0.29 & 4.82 & 64 & 3 & 0.18 & $\$ 11,956$ \\
\hline Italy & 98 & 0.034 & 0.104 & 0.49 & $1.4 \%$ & $1.0 \%$ & 0.51 & 0.12 & 8.33 & 62 & 1 & 0.14 & $\$ 20,462$ \\
\hline Japan & 768 & 0.021 & 0.128 & 0.41 & $0.8 \%$ & $0.0 \%$ & 1.69 & 0.73 & 8.98 & 65 & 4 & 0.01 & $\$ 28,110$ \\
\hline Malaysia & 222 & 0.069 & 0.102 & 0.46 & $2.7 \%$ & $1.8 \%$ & 0.80 & 1.07 & 6.78 & 76 & 4 & 0.03 & $\$ 2,521$ \\
\hline Mexico & 32 & 0.038 & 0.085 & 0.07 & $1.1 \%$ & $1.1 \%$ & 0.18 & 0.15 & 5.35 & 60 & 1 & 0.08 & $\$ 3,714$ \\
\hline Netherlands & 89 & 0.055 & 0.092 & 0.36 & $2.3 \%$ & $1.7 \%$ & 1.28 & 0.41 & 10 & 64 & 2 & 0.20 & $\$ 20,058$ \\
\hline New Zealand & 18 & 0.073 & 0.093 & 0.40 & $2.2 \%$ & $1.9 \%$ & 0.54 & 0.40 & 10 & 70 & 4 & 0.26 & $\$ 12,098$ \\
\hline Norway & 46 & 0.079 & 0.146 & 0.28 & $2.7 \%$ & $2.3 \%$ & 0.89 & 0.15 & 10 & 74 & 4 & 0.13 & $\$ 27,630$ \\
\hline Pakistan & 25 & 0.052 & 0.136 & 0.65 & $0.9 \%$ & $0.9 \%$ & 0.23 & 0.09 & 3.03 & - & 5 & 0.23 & $\$ 396$ \\
\hline Philippines & 22 & 0.082 & 0.094 & 0.40 & $1.1 \%$ & $1.3 \%$ & 0.29 & 0.21 & 2.73 & 65 & 3 & 0.47 & $\$ 708$ \\
\hline Portugal & 21 & 0.033 & 0.088 & 0.51 & $2.5 \%$ & $1.0 \%$ & 0.63 & 0.08 & 8.68 & 36 & 3 & 0.15 & $\$ 8,207$ \\
\hline Singapore & 107 & 0.058 & 0.142 & 0.35 & $3.2 \%$ & $4.7 \%$ & 0.95 & 1.23 & 8.57 & 78 & 4 & 0.07 & $\$ 13,665$ \\
\hline South Africa & 30 & 0.039 & 0.083 & 0.24 & $0.6 \%$ & $0.8 \%$ & 0.79 & 1.31 & 4.42 & 70 & 5 & 0.10 & $\$ 3,343$ \\
\hline South Korea & 58 & 0.053 & 0.149 & 0.45 & $4.7 \%$ & $2.4 \%$ & 0.81 & 0.25 & 5.35 & 62 & 2 & 0.14 & $\$ 6,819$ \\
\hline Spain & 59 & 0.038 & 0.053 & 0.33 & $2.2 \%$ & $1.5 \%$ & 0.72 & 0.18 & 7.8 & 64 & 4 & 0.23 & $\$ 14,178$ \\
\hline Sweden & 103 & 0.080 & 0.167 & 0.14 & $2.1 \%$ & $1.5 \%$ & 1.09 & 0.38 & 10 & 83 & 3 & 0.08 & $\$ 28,724$ \\
\hline Switzerland & 96 & 0.043 & 0.137 & 0.35 & $0.6 \%$ & $0.2 \%$ & 1.78 & 0.71 & 10 & 68 & 2 & 0.15 & $\$ 34,217$ \\
\hline Thailand & 140 & 0.066 & 0.098 & 0.35 & $5.0 \%$ & $3.8 \%$ & 0.68 & 0.26 & 6.25 & 64 & 2 & 0.06 & $\$ 1,735$ \\
\hline Turkey & 24 & 0.073 & 0.092 & 0.08 & $2.2 \%$ & $0.1 \%$ & 0.14 & 0.06 & 5.18 & 51 & 2 & 0.28 & $\$ 2,636$ \\
\hline United Kingdom & 485 & 0.069 & 0.120 & 0.21 & $2.2 \%$ & $1.6 \%$ & 0.74 & 0.76 & 8.57 & 78 & 5 & 0.05 & $\$ 17,883$ \\
\hline United States & 1,818 & 0.090 & 0.153 & 0.10 & $2.1 \%$ & $1.6 \%$ & 1.31 & 0.58 & 10 & 71 & 5 & 0.01 & $\$ 23,471$ \\
\hline
\end{tabular}


Table 3. Pairwise Correlations of main variables.

In this table we present correlations for the following variables that appear in our empirical work: (1) a country average of the company EBITDA-toassets ratio, RISK2, (2) country imputed riskiness score, RISK3, (3) average annual country real GDP-per-capita growth for 1992-2002, (4) average annual total factor productivity growth for 1992-2000 (smaller sample is due to data availability in PWT Version 6.1), (5) claims on private sector by deposit money banks and other financial institutions as share of GDP, (6) stock market capitalization as share of GDP, (7) Measure of earnings smoothing computed as $\mathrm{ES}_{2}=1-\mathrm{ES}_{1}$ where $\mathrm{ES}_{1}$ is the measure computed in Ball, Kothari, Robin (2000), (8) Anti-director rights index, (9) Rule of Law, (10) Rating on Quality of Accounting Standards, and (11) Herfindahl index per country-year. Items five and six are from Demirguç-Kunt and Levine (2001). Items eight through ten are from La Porta et al. (1998). Higher values of the earnings smoothing measure are associated higher levels of smoothing. Pairwise correlations are presented in percentage values. P-values for the significance of the correlations are presented in parentheses below.

\begin{tabular}{|c|c|c|c|c|c|c|c|c|c|c|}
\hline & $\begin{array}{c}\text { RISK2 } \\
\sigma_{c}\end{array}$ & $\begin{array}{c}\text { RISK3 } \\
\Omega_{c}\end{array}$ & $\begin{array}{c}\text { GDP } \\
\text { Growth }\end{array}$ & $\begin{array}{l}\text { TFP } \\
\text { Growth }\end{array}$ & $\begin{array}{l}\text { Private } \\
\text { Credit }\end{array}$ & $\begin{array}{c}\text { Market } \\
\text { Cap }\end{array}$ & $\begin{array}{c}\text { Earnings } \\
\text { Smoothing }\end{array}$ & $\begin{array}{c}\text { Anti- } \\
\text { director }\end{array}$ & $\begin{array}{l}\text { Rule of } \\
\text { Law }\end{array}$ & Disclosure \\
\hline $\begin{array}{c}\text { RISK3, } \\
\Omega_{c}\end{array}$ & $\begin{array}{c}0.36 \\
(0.03)\end{array}$ & 1.00 & & & & & & & & \\
\hline GDP Growth & $\begin{array}{c}0.15 \\
(0.39)\end{array}$ & $\begin{array}{c}0.03 \\
(0.85)\end{array}$ & 1.00 & & & & & & & \\
\hline TFP Growth & $\begin{array}{c}0.16 \\
(0.33)\end{array}$ & $\begin{array}{c}0.14 \\
(0.40)\end{array}$ & $\begin{array}{c}0.76 \\
(0.00)\end{array}$ & 1.00 & & & & & & \\
\hline Private Credit & $\begin{array}{c}0.07 \\
(0.65)\end{array}$ & $\begin{array}{c}0.39 \\
(0.02)\end{array}$ & $\begin{array}{l}-0.07 \\
(0.68)\end{array}$ & $\begin{array}{l}-0.16 \\
(0.34)\end{array}$ & 1.00 & & & & & \\
\hline Market Cap & $\begin{array}{c}0.15 \\
(0.37)\end{array}$ & $\begin{array}{c}0.17 \\
(0.32)\end{array}$ & $\begin{array}{l}-0.04 \\
(0.80)\end{array}$ & $\begin{array}{c}0.02 \\
(0.89)\end{array}$ & $\begin{array}{c}0.57 \\
(0.00)\end{array}$ & 1.00 & & & & \\
\hline $\begin{array}{c}\text { Earnings } \\
\text { Smoothing }\end{array}$ & $\begin{array}{c}-0.43 \\
(0.01)\end{array}$ & $\begin{array}{l}-0.21 \\
(0.20)\end{array}$ & $\begin{array}{l}-0.11 \\
(0.49)\end{array}$ & $\begin{array}{l}-0.13 \\
(0.42)\end{array}$ & $\begin{array}{l}-0.06 \\
(0.74)\end{array}$ & $\begin{array}{l}-0.14 \\
(0.41)\end{array}$ & 1.00 & & & \\
\hline $\begin{array}{c}\text { Anti-director } \\
\quad(A D R)\end{array}$ & $\begin{array}{c}0.27 \\
(0.10)\end{array}$ & $\begin{array}{c}0.11 \\
(0.53)\end{array}$ & $\begin{array}{c}0.08 \\
(0.64)\end{array}$ & $\begin{array}{c}0.19 \\
(0.26)\end{array}$ & $\begin{array}{c}0.16 \\
(0.34)\end{array}$ & $\begin{array}{c}0.46 \\
(0.00)\end{array}$ & $\begin{array}{l}-0.15 \\
(0.36)\end{array}$ & 1.00 & & \\
\hline $\begin{array}{c}\text { Disclosure } \\
\text { (ASR) }\end{array}$ & $\begin{array}{c}0.51 \\
(0.00)\end{array}$ & $\begin{array}{c}0.49 \\
(0.00)\end{array}$ & $\begin{array}{c}0.14 \\
(0.44)\end{array}$ & $\begin{array}{c}0.21 \\
(0.22)\end{array}$ & $\begin{array}{c}0.48 \\
(0.00)\end{array}$ & $\begin{array}{c}0.55 \\
(0.00)\end{array}$ & $\begin{array}{l}-0.39 \\
(0.02)\end{array}$ & $\begin{array}{c}0.29 \\
(0.10)\end{array}$ & 1.00 & \\
\hline $\begin{array}{l}\text { Rule of Law } \\
\quad(R L)\end{array}$ & $\begin{array}{c}0.17 \\
(0.30)\end{array}$ & $\begin{array}{c}0.36 \\
(0.03)\end{array}$ & $\begin{array}{c}0.06 \\
(0.74)\end{array}$ & $\begin{array}{c}0.03 \\
(0.86)\end{array}$ & $\begin{array}{c}0.61 \\
(0.00)\end{array}$ & $\begin{array}{c}0.19 \\
(0.25)\end{array}$ & $\begin{array}{l}-0.10 \\
(0.54)\end{array}$ & $\begin{array}{l}-0.07 \\
(0.67)\end{array}$ & $\begin{array}{c}0.42 \\
(0.01)\end{array}$ & 1.00 \\
\hline $\begin{array}{l}\text { Herfindahl } \\
\text { Index }\end{array}$ & $\begin{array}{l}-0.10 \\
(0.55)\end{array}$ & $\begin{array}{l}-0.41 \\
(0.01)\end{array}$ & $\begin{array}{l}-0.19 \\
(0.26)\end{array}$ & $\begin{array}{l}-0.11 \\
(0.50)\end{array}$ & $\begin{array}{l}-0.49 \\
(0.00)\end{array}$ & $\begin{array}{l}-0.41 \\
(0.01)\end{array}$ & $\begin{array}{c}0.22 \\
(0.18)\end{array}$ & $\begin{array}{l}-0.10 \\
(0.53)\end{array}$ & $\begin{array}{l}-0.47 \\
(0.00)\end{array}$ & $\begin{array}{l}-0.54 \\
(0.00)\end{array}$ \\
\hline
\end{tabular}


Table 4 Panel A. Firm Level Risk-taking Regressions

In this table we present firm-level regressions of the company risk-taking proxy $\sigma_{i, c}$, investor protection indicators, and control variables for firm size, firm earnings smoothing, competition within the county, and the country financing market development. The risk-taking proxy is the time series standard deviation of the EBITDA/Assets company ratio, computed for 1992-2002. We include only firms for which there are at least five annual observations on EBITDA/Assets. T-statistics are reported in parentheses below the corresponding coefficients. Earnings smoothing is one minus the firm's ratio of firm-level standard deviations of operating income and operating cash flow, both scaled by lagged total assets. The higher the measure, the higher the propensity to smooth earnings. Firm size is the average total assets over 1992-2002. Reported results are obtained from regressions with 3-digit SIC industry code fixed effects (not shown); in addition the regression includes as control the number of observations used to estimate the risk taking proxy (not reported). We have required that the rule of law indicator is available for the country of residence of the companies in our sample. We consider only firms in the manufacturing industry (SIC 2000-3999). For the definition of market capitalization and private credit refer to Table 1.

Dependent Variable: Company Risk-taking RISK1, $\sigma_{i, c}$

$(1)$

0.0013

(8.15)

Rule of Law

Anti-Director Index

Earnings Smoothing

Log (Firm Size)

Country Private Credit

Country Market Capitalization

Country Herfindahl Index

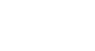

(2)

0.0055

(7.90)

(3)

(4)

0.0007

(3.56)

0.0039

(4.49)

0.0048

(6.15)

(7.03)

$-0.0099$

$(-10.34)$

$-0.0137$

$(-27.86)$

$-0.0065$

$(-2.54)$

$-0.0180$

$(-4.71)$

$-0.0463$

$(-2.68)$

$-0.0454$

$(-2.65)$

$-0.0095$

$(-9.86)$

$-0.0136$

$(-27.39)$

$-0.0104$

(-3.06)

$-0.0203$

$(-4.13)$

0.0031

(0.17)

$(-1.52)$

5,234

$20.4 \%$

157.5

5,234

$20.6 \%$

5,164

$20.4 \%$

155.2

$22.1 \%$

156.4

$-15,400.0$

$-15,400.0$

$-15,200.0$ 
Table 4 Panel B. Firm Level Growth Regressions

In this table we present the firm-level regressions of assets and sales growth versus risk-taking proxy, $\sigma_{i, c}$, investor protection indicators, and controls for firm size and financial market development. As an alternative proxy for risk-taking we include the instrumented risk-taking proxy, $\bar{\sigma}_{i, c}=E\left(\sigma_{i, c} \mid A D R, A S R, R L\right)$. Assets and sales growth are winsorized at the $0.5 \%$ level on both sides of the distribution. T-statistics are reported in parentheses below the corresponding coefficients. Assets growth is computed as the growth in $\$$ assets of the firm. Sales growth is defined analogously. Firm size is the average total assets over 1992-2002. Reported results are obtained from regressions with 3-digit SIC industry code fixed effects (not reported); in addition the regression includes as control the number of observations used to estimate the standard deviation of the industry-adjusted EBITDA/Assets ratio (not reported). We include only firms for which there are at least five annual observations on EBITDA/Assets. We have required that the rule of law indicator is available for the country of residence of the companies in our sample. We consider only manufacturing industry constituents (SIC 2000-3999).

\begin{tabular}{|c|c|c|c|c|c|c|}
\hline & \multicolumn{6}{|c|}{ Dependent Variable } \\
\hline & \multicolumn{3}{|c|}{ Company Asset Growth } & \multicolumn{3}{|c|}{ Company Sales Growth } \\
\hline & $(1)$ & $(2)$ & (3) & (4) & $(5)$ & $(6)$ \\
\hline RISK1, $\sigma_{i, c}$ & $\begin{array}{c}0.1737 \\
(5.60)\end{array}$ & $\begin{array}{c}0.0816 \\
(2.65)\end{array}$ & & $\begin{array}{l}0.1799 \\
(5.16)\end{array}$ & $\begin{array}{l}0.1013 \\
(2.90)\end{array}$ & \\
\hline Predicted RISK1, $\bar{\sigma}_{i, c}$ & & & $\begin{array}{l}2.5538 \\
(16.87)\end{array}$ & & & $\begin{array}{l}2.2716 \\
(13.35)\end{array}$ \\
\hline Disclosure & & $\begin{array}{l}0.0014 \\
(3.44)\end{array}$ & & & $\begin{array}{l}0.0018 \\
(3.98)\end{array}$ & \\
\hline Rule of Law & & $\begin{array}{c}0.0106 \\
(5.61)\end{array}$ & & & $\begin{array}{l}0.0066 \\
(3.11)\end{array}$ & \\
\hline Anti-Director Index & & $\begin{array}{l}0.0191 \\
(11.37) \\
\end{array}$ & & & $\begin{array}{l}0.0162 \\
(8.55) \\
\end{array}$ & \\
\hline Log (Firm Size) & $\begin{array}{l}0.0082 \\
(6.87)\end{array}$ & $\begin{array}{l}0.0078 \\
(6.62)\end{array}$ & $\begin{array}{l}0.0067 \\
(6.16)\end{array}$ & $\begin{array}{l}0.0081 \\
(6.08)\end{array}$ & $\begin{array}{l}0.0076 \\
(5.77)\end{array}$ & $\begin{array}{l}0.0063 \\
(5.13)\end{array}$ \\
\hline Country Private Credit & $\begin{array}{c}-0.0025 \\
(-0.48)\end{array}$ & $\begin{array}{l}-0.025 \\
(-3.49)\end{array}$ & $\begin{array}{c}-0.0175 \\
(-3.37)\end{array}$ & $\begin{array}{c}-0.0058 \\
(-1.01)\end{array}$ & $\begin{array}{c}-0.0173 \\
(-2.15)\end{array}$ & $\begin{array}{l}-0.0188 \\
(-3.23)\end{array}$ \\
\hline Country Market Capitalization & $\begin{array}{c}-0.0067 \\
(-0.90)\end{array}$ & $\begin{array}{l}-0.064 \\
(-5.91)\end{array}$ & $\begin{array}{c}-0.0736 \\
(-8.80)\end{array}$ & $\begin{array}{l}-0.0206 \\
(-2.46)\end{array}$ & $\begin{array}{c}-0.0819 \\
(-6.73)\end{array}$ & $\begin{array}{c}-0.0805 \\
(-8.57)\end{array}$ \\
\hline Number of observations & 5,234 & 5,164 & 5,164 & 5,226 & 5,156 & 5,156 \\
\hline$R$-squared (\%) & $2.5 \%$ & $9.4 \%$ & $8.1 \%$ & $2.2 \%$ & $6.8 \%$ & $5.7 \%$ \\
\hline $\begin{array}{l}\text { F-statistic } \\
\text { Akaike Information }\end{array}$ & 14.0 & 43.3 & 64.5 & 13.0 & 28.8 & 43.1 \\
\hline $\begin{array}{l}\text { Criterion (AIC) } \\
\text { Bayes Information }\end{array}$ & -6910.0 & -7080.0 & -7060.0 & -5780.0 & -5870.0 & -5860.0 \\
\hline Criterion (BIC) & -6880.00 & -7020.00 & -7020.00 & -5750.00 & -5810.00 & -5820.00 \\
\hline
\end{tabular}


Table 5 Panel A. Risk-taking and Corporate Governance

We analyze the relationship between investor protection, disclosure, and rule of law proxies and the risk-taking proxies, RISK2 ( $\left.\sigma_{c}\right)$ and RISK3 $\left(\Omega_{c}\right)$.A detailed computation of both risk-taking measures and the real GDP-per-capita growth is presented in Table 1 . As explanatory variables we include anti-director rights (ADR), the quality of the accounting standard (ASR), and the rule of law (RL) (from La Porta et al. (1998)). As controls we include a Herfindahl index, claims on private sector by deposit money banks and other financial institutions as share of GDP, stock market capitalization as share of GDP (the latter two measures from Demirguç-Kunt and Levine (2001)), earnings smoothing proxy (refer to Table 1 for definition) and the logarithm of 1991 GDP-per-capita (in US\$). We consider companies in the manufacturing industry only, SIC codes 2000 through 3999.

\begin{tabular}{|c|c|c|c|c|c|c|c|c|}
\hline & \multicolumn{8}{|c|}{ Dependent Variable: } \\
\hline & \multicolumn{4}{|c|}{$\operatorname{RISK} 2\left(\sigma_{c}\right)$} & \multicolumn{4}{|c|}{$\operatorname{RISK3}\left(\Omega_{c}\right)$} \\
\hline & (1) & (2) & (3) & (4) & (5) & (6) & (7) & (8) \\
\hline \multirow[t]{2}{*}{ Disclosure } & 0.0010 & & & 0.0009 & 0.0010 & & & 0.0009 \\
\hline & $(2.44)$ & & & $(2.28)$ & $(2.02)$ & & & $(1.97)$ \\
\hline \multirow[t]{2}{*}{ Rule of Law } & & 0.0055 & & 0.0040 & & -0.0014 & & -0.0024 \\
\hline & & $(1.87)$ & & $(1.58)$ & & $(-0.35)$ & & $(-0.54)$ \\
\hline \multirow[t]{2}{*}{ Anti-Director Index } & & & 0.0028 & 0.0021 & & & 0.0032 & 0.0005 \\
\hline & & & $(1.15)$ & $(0.81)$ & & & $(0.92)$ & $(0.13)$ \\
\hline \multirow[t]{2}{*}{ Earnings Smoothing } & -0.0448 & -0.0676 & -0.0553 & -0.0487 & & & & \\
\hline & $(-1.58)$ & $(-3.21)$ & $(-2.53)$ & $(-1.83)$ & & & & \\
\hline \multirow[t]{2}{*}{ Herfindahl Index } & 0.0251 & 0.0342 & 0.0052 & 0.0437 & -0.0463 & -0.0552 & -0.0732 & -0.0322 \\
\hline & $(0.7)$ & $(0.77)$ & $(0.11)$ & $(1.22)$ & $(-1.27)$ & $(-1.8)$ & $(-1.65)$ & $(-1.51)$ \\
\hline \multirow[t]{2}{*}{ Private Credit } & -0.0007 & -0.0006 & 0.0012 & -0.0032 & 0.0149 & 0.0160 & 0.0179 & 0.0132 \\
\hline & $(-0.07)$ & $(-0.05)$ & $(0.1)$ & $(-0.34)$ & $(0.93)$ & $(1.2)$ & $(1.12)$ & $(0.98)$ \\
\hline \multirow[t]{2}{*}{ Market Capitalization } & -0.0061 & 0.0078 & -0.0005 & -0.0059 & 0.0008 & 0.0100 & 0.0025 & 0.0049 \\
\hline & $(-0.54)$ & $(0.82)$ & $(-0.04)$ & $(-0.53)$ & $(-1.29)$ & $(-0.72)$ & $(-0.93)$ & $(-1.26)$ \\
\hline \multirow[t]{2}{*}{1991 GDP-per-capita } & -0.0012 & -0.0087 & 0.0003 & -0.0060 & 0.0047 & -0.0025 & 0.0037 & 0.0000 \\
\hline & $(-0.49)$ & $(-1.76)$ & $(0.09)$ & $(-1.2)$ & $(0.79)$ & $(0.57)$ & $(0.76)$ & $(0.81)$ \\
\hline Number of observations & 35 & 38 & 38 & 35 & 35 & 38 & 38 & 35 \\
\hline$R$-squared (\%) & $38.9 \%$ & $30.4 \%$ & $22.8 \%$ & $46.9 \%$ & $41.7 \%$ & $29.7 \%$ & $28.9 \%$ & $43.0 \%$ \\
\hline F-statistic & 3.7 & 2.4 & 2.0 & 3.8 & 7.8 & 3.6 & 3.8 & 5.0 \\
\hline $\begin{array}{l}\text { Akaike Information } \\
\text { Criterion (AIC) }\end{array}$ & -182.2 & -196.9 & -193.0 & -183.2 & -148.3 & -156.2 & -155.7 & -145.1 \\
\hline
\end{tabular}


Table 5 Panel B. Economic Growth and Risk-taking

We analyze the relationship between annual real GDP-per-capita growth and risk-taking measures: RISK2 $\left(\sigma_{c}\right)$ and RISK3 $\left(\Omega_{c}\right)$. Real GDP-per-capita growth is computed using IMF International Financial Statistics database. A detailed computation of both risk-taking measures and the real GDP-per-capita growth is presented in Table 1. As alternative risk-taking proxies we use instruments for both RISK2 and RISK3, $\bar{\sigma}_{c}=E\left(\sigma_{c} \mid A D R, A S R, R L\right)$ and $\bar{\Omega}_{c}=E\left(\Omega_{c} \mid A D R, R L, A S R\right)$. As control variables we include anti-director rights (ADR), the quality of the accounting standard (ASR), and the rule of law (RL) (from La Porta et al. (1998)). Further controls include claims on private sector by deposit money banks and other financial institutions as share of GDP, stock market capitalization as share of GDP (both measures from Demirguç-Kunt and Levine (2001)), average schooling years in the total population over 25 in 1990 (from Barro and Lee (1993)), and the logarithm of 1991 GDP-per-capita in US dollars. We consider companies in the manufacturing industry only (SIC codes 2000 through 3999). Regressions (2) and (3) present results using risk-taking proxy RISK2, while (4) and (5) present results using RISK3.

\begin{tabular}{|c|c|c|c|c|c|}
\hline & \multicolumn{5}{|c|}{ Dependent Variable: Average Real GDP-per-capita growth, 1992-2002 } \\
\hline & $(1)$ & $(2)$ & $(3)$ & (4) & $(5)$ \\
\hline RISK2, $\sigma_{c}$ & & $\begin{array}{l}0.0047 \\
(0.05)\end{array}$ & & & \\
\hline Predicted RISK2, $\bar{\sigma}_{c}$ & & & $\begin{array}{l}0.4187 \\
(1.69)\end{array}$ & & \\
\hline RISK3, $\Omega_{c}$ & & & & $\begin{array}{l}0.0072 \\
(0.08)\end{array}$ & \\
\hline Predicted RISK3, $\bar{\Omega}_{c}$ & & & & & $\begin{array}{c}0.4359 \\
(2.18) \\
\end{array}$ \\
\hline Anti-Director Index & $\begin{array}{c}0.0001 \\
(0.07)\end{array}$ & $\begin{array}{l}0.0001 \\
(0.06)\end{array}$ & & $\begin{array}{c}0.0001 \\
(0.07)\end{array}$ & \\
\hline Disclosure & $\begin{array}{c}0.0003 \\
(1.24)\end{array}$ & $\begin{array}{c}0.0003 \\
(1.24)\end{array}$ & & $\begin{array}{c}0.0002 \\
(1.04)\end{array}$ & \\
\hline Rule of Law & $\begin{array}{l}0.0043 \\
(2.32)\end{array}$ & $\begin{array}{c}0.0043 \\
(2.25) \\
\end{array}$ & & $\begin{array}{c}0.0043 \\
(2.34)\end{array}$ & \\
\hline Private Credit & $\begin{array}{c}0.0008 \\
(0.11)\end{array}$ & $\begin{array}{c}0.0008 \\
(0.11)\end{array}$ & $\begin{array}{l}0.0037 \\
(0.47)\end{array}$ & $\begin{array}{c}0.0007 \\
(0.1)\end{array}$ & $\begin{array}{c}0.0031 \\
(0.44)\end{array}$ \\
\hline Market Capitalization & $\begin{array}{l}-0.0039 \\
(-0.72)\end{array}$ & $\begin{array}{c}-0.0039 \\
(-0.72)\end{array}$ & $\begin{array}{c}-0.0082 \\
(-1.05)\end{array}$ & $\begin{array}{c}-0.0038 \\
(-0.7)\end{array}$ & $\begin{array}{r}-0.0073 \\
(-1.07)\end{array}$ \\
\hline Schooling, 1990 & $\begin{array}{c}0.0001 \\
(0.1)\end{array}$ & $\begin{array}{r}0.0001 \\
(0.09)\end{array}$ & $\begin{array}{c}0 \\
(-0.02)\end{array}$ & $\begin{array}{l}0.0001 \\
(0.09)\end{array}$ & $\begin{array}{r}-0.0001 \\
(-0.11)\end{array}$ \\
\hline 1991 GDP-per-capita (\$) & $\begin{array}{c}-0.0104 \\
(-2.97) \\
\end{array}$ & $\begin{array}{c}-0.0104 \\
(-2.99) \\
\end{array}$ & $\begin{array}{c}-0.0034 \\
(-0.98) \\
\end{array}$ & $\begin{array}{c}-0.0104 \\
(-2.91) \\
\end{array}$ & $\begin{array}{r}-0.0064 \\
(-1.72) \\
\end{array}$ \\
\hline Number of observations & 35 & 35 & 35 & 35 & 35 \\
\hline$R$-squared (\%) & $32.0 \%$ & $32.0 \%$ & $12.1 \%$ & $32.0 \%$ & $20.5 \%$ \\
\hline F-statistic & 2.0 & 1.8 & 0.8 & 2.1 & 1.2 \\
\hline Akaike Information Criterion & -212.1 & -210.1 & -207.2 & -210.2 & -210.7 \\
\hline Bayes Information Criterion & -199.7 & -196.1 & -197.8 & -196.2 & -201.4 \\
\hline
\end{tabular}


Table 5 Panel C. Total Factor Productivity Growth and Risk-taking

We analyze the relationship between annual total factor productivity growth and risk-taking measures: RISK2 $\left(\sigma_{c}\right)$ and RISK3 $\left(\Omega_{c}\right)$. Total factor productivity is computed using the Penn World Tables, version 6.1. A detailed computation of both risk-taking measures and the total factor productivity growth is presented in Table 1. As alternative risk-taking proxies we use instruments for both risk proxies, $\bar{\sigma}_{c}=E\left(\sigma_{c} \mid A D R, A S R, R L\right)$ and $\bar{\Omega}_{c}=E\left(\Omega_{c} \mid A D R, R L, A S R\right)$. As control variables we include anti-director rights (ADR), the quality of the accounting standard (ASR), and the rule of law (RL) (from La Porta et al. (1998)). Further controls include claims on private sector by deposit money banks and other financial institutions as share of GDP, stock market capitalization as share of GDP (both measures from Demirguç-Kunt and Levine (2001)), average schooling years in the total population over 25 in 1990 (from Barro and Lee (1993)), and the 1991 TFP growth. We consider companies in the manufacturing industry only (SIC codes 2000 through 3999). Regressions (2) and (3) present results for RISK2, while (4) and (5) use RISK3.

\begin{tabular}{|c|c|c|c|c|c|}
\hline & \multicolumn{5}{|c|}{ Dependent Variable: Average TFP growth, 1992-2000 } \\
\hline & $(1)$ & $(2)$ & (3) & (4) & $(5)$ \\
\hline RISK2, $\sigma_{c}$ & & $\begin{array}{l}0.0959 \\
(0.80)\end{array}$ & & & \\
\hline Predicted RISK2, $\bar{\sigma}_{c}$ & & & $\begin{array}{l}1.3332 \\
(4.76)\end{array}$ & & \\
\hline $\operatorname{RISK} 3, \Omega_{c}$ & & & & $\begin{array}{l}0.0433 \\
(0.55)\end{array}$ & \\
\hline Predicted RISK3, $\bar{\Omega}_{c}$ & & & & & $\begin{array}{l}0.5082 \\
(2.55) \\
\end{array}$ \\
\hline Anti-Director Index & $\begin{array}{l}0.0021 \\
(1.94)\end{array}$ & $\begin{array}{c}0.0018 \\
(1.4)\end{array}$ & & $\begin{array}{l}0.0021 \\
(1.91)\end{array}$ & \\
\hline Disclosure & $\begin{array}{l}0.0007 \\
(2.58)\end{array}$ & $\begin{array}{c}0.0006 \\
(2.38)\end{array}$ & & $\begin{array}{c}0.0006 \\
(2.5)\end{array}$ & \\
\hline Rule of Law & $\begin{array}{c}0.0014 \\
(1.45)\end{array}$ & $\begin{array}{c}0.0014 \\
(1.56) \\
\end{array}$ & & $\begin{array}{c}0.0014 \\
(1.47) \\
\end{array}$ & \\
\hline Private Credit & $\begin{array}{l}-0.0125 \\
(-2.56)\end{array}$ & $\begin{array}{l}-0.0116 \\
(-2.46)\end{array}$ & $\begin{array}{l}-0.0080 \\
(-2.09)\end{array}$ & $\begin{array}{l}-0.0132 \\
(-2.44)\end{array}$ & $\begin{array}{l}-0.0136 \\
(-3.33)\end{array}$ \\
\hline Market Capitalization & $\begin{array}{l}-0.0046 \\
(-0.55)\end{array}$ & $\begin{array}{l}-0.0038 \\
(-0.45)\end{array}$ & $\begin{array}{l}-0.0059 \\
(-0.71)\end{array}$ & $\begin{array}{l}-0.0041 \\
(-0.47)\end{array}$ & $\begin{array}{l}0.0020 \\
(0.32)\end{array}$ \\
\hline Schooling, 1990 & $\begin{array}{c}-0.0010 \\
(-0.9)\end{array}$ & $\begin{array}{c}-0.0011 \\
(-1)\end{array}$ & $\begin{array}{l}-0.0002 \\
(-0.23)\end{array}$ & $\begin{array}{l}-0.0011 \\
(-0.92)\end{array}$ & $\begin{array}{l}-0.0008 \\
(-0.74)\end{array}$ \\
\hline 1991 TFP Growth & $\begin{array}{l}0.1487 \\
(2.59) \\
\end{array}$ & $\begin{array}{c}0.1414 \\
(2.41) \\
\end{array}$ & $\begin{array}{l}0.1275 \\
(2.82) \\
\end{array}$ & $\begin{array}{c}0.1446 \\
(2.47) \\
\end{array}$ & $\begin{array}{l}0.1316 \\
(2.21) \\
\end{array}$ \\
\hline $\begin{array}{l}\text { Number of observations } \\
\text { R-squared (\%) }\end{array}$ & $\begin{array}{c}35 \\
37.3 \%\end{array}$ & $\begin{array}{c}35 \\
38.8 \%\end{array}$ & $\begin{array}{c}35 \\
30.3 \%\end{array}$ & $\begin{array}{c}35 \\
38.1 \%\end{array}$ & $\begin{array}{c}35 \\
29.5 \%\end{array}$ \\
\hline F-statistic & 5.2 & 5.1 & 7.3 & 4.3 & 3.4 \\
\hline Akaike Information Criterion & -221.1 & -219.9 & -221.4 & -219.6 & -221.0 \\
\hline Bayes Information Criterion & -208.6 & -205.9 & -212.1 & -205.6 & -211.7 \\
\hline
\end{tabular}


Figure 1. Risk-taking and disclosure.

Risk-taking proxies, RISK2 $\left(\sigma_{c}\right)$ and RISK3 $\left(\Omega_{c}\right)$, and the quality of accounting standards rating (from La Porta et al. (1998)). The fitted line represents the slope from a quintile regression of the risk-taking proxy on constant and disclosure ranking.
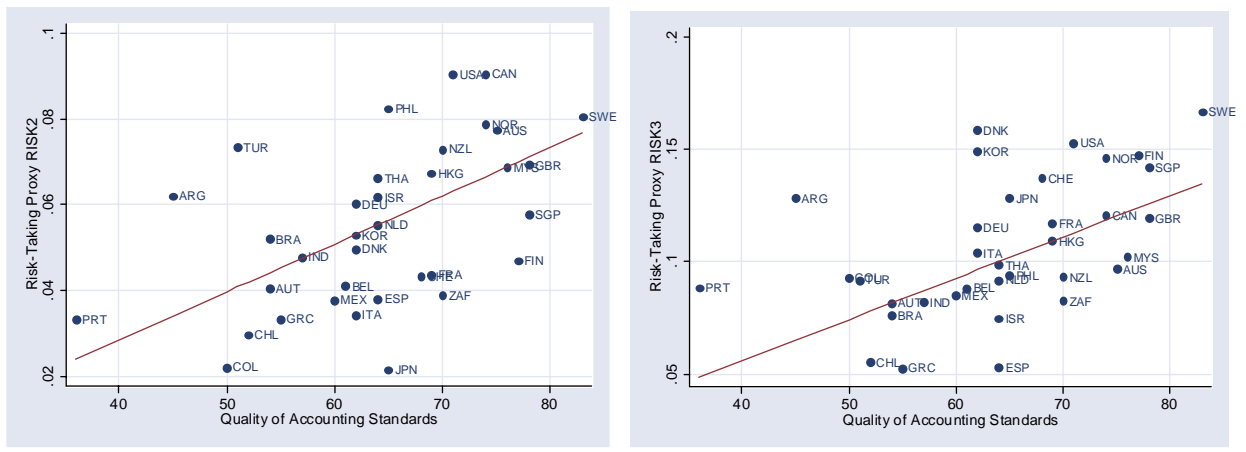

Figure 2. Risk-taking and anti-director rights.

Risk-taking proxies, RISK2 $\left(\sigma_{c}\right)$ and RISK3 $\left(\Omega_{c}\right)$, and anti-director rights index (from La Porta et al. (1998)). The fitted line represents the slope from a quintile regression of the risk-taking proxy on anti-director rights index.
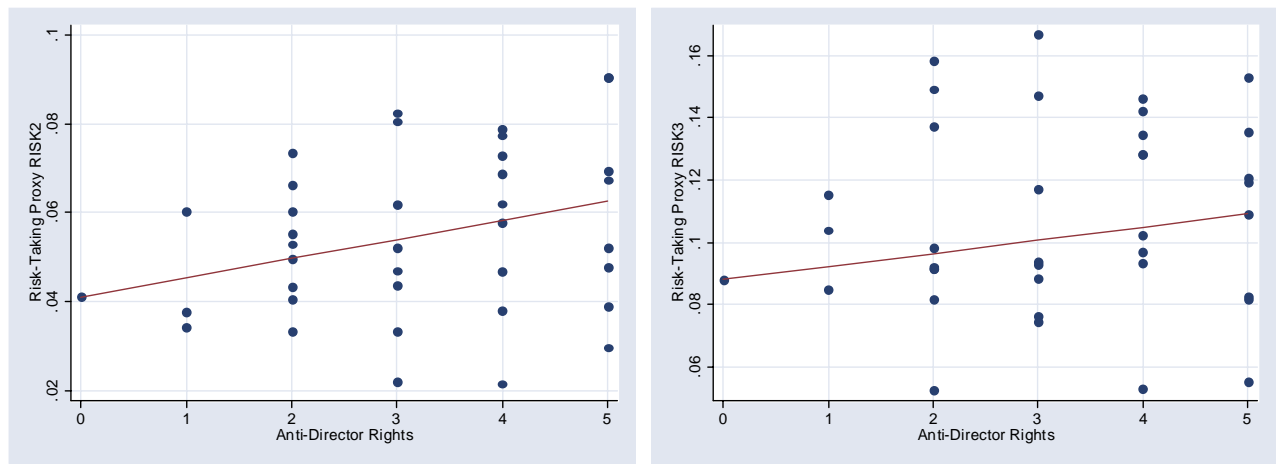

Figure 3. Risk-taking and rule of law.

Risk-taking proxies, RISK2 $\left(\sigma_{c}\right)$ and RISK3 $\left(\Omega_{c}\right)$, and the rule of law indicator (from La Porta et al. (1998)). The fitted line represents the slope from a quintile regression of the risk-taking proxy on constant and the rule of law indicator.
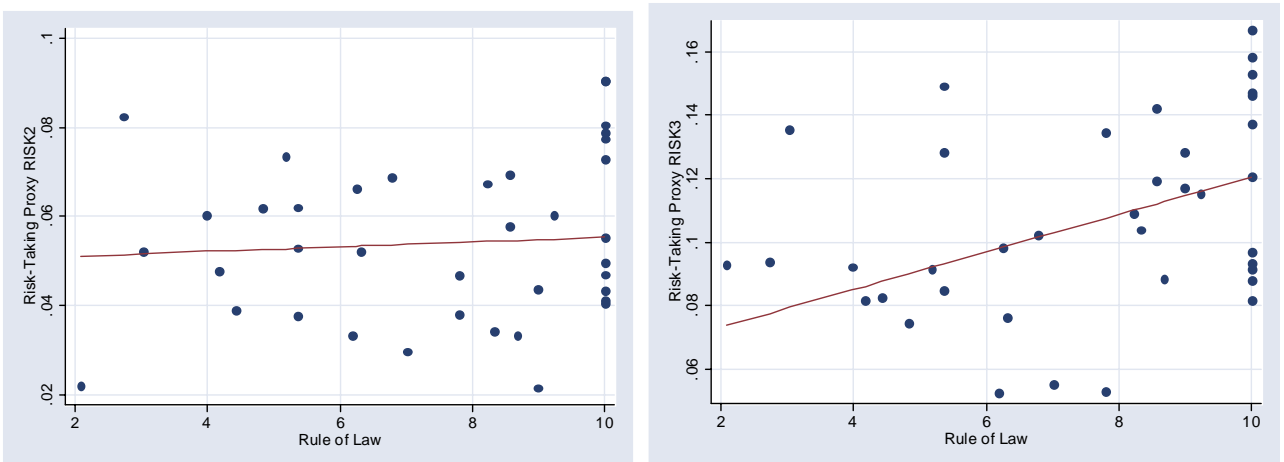
Figure 4. GDP growth and risk-taking.

Predicted risk-taking proxies, $\bar{\sigma}_{c}$ and $\bar{\Omega}_{c}$, and average real GDP-per-capita growth. The measures have been computed for the sample 1992-2002, using Compustat Global Industrial/Commercial database. The fitted line represents the slope from a quintile regression of real GDP-per-capita growth on constant and the risk-taking proxy.
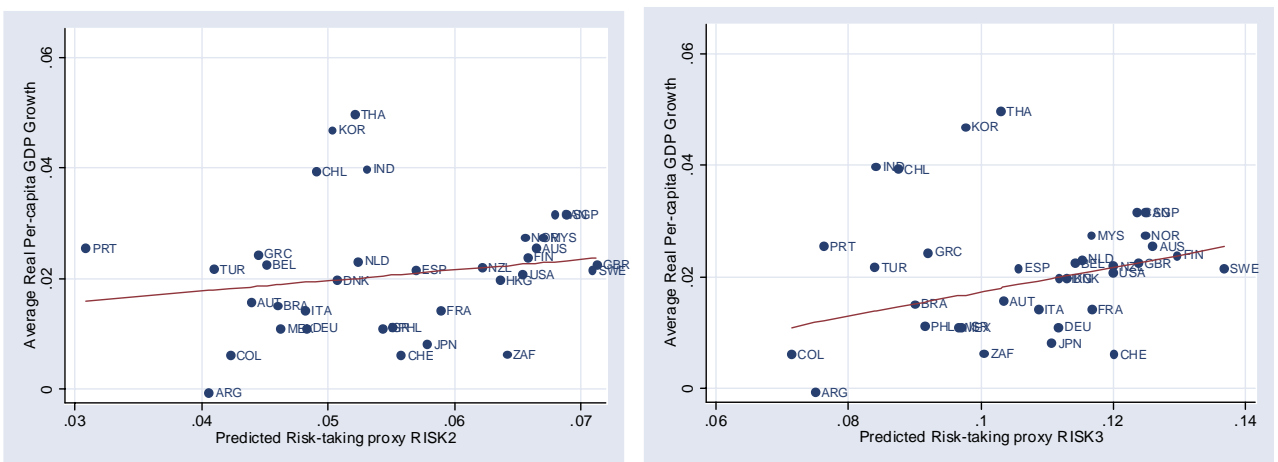

Figure 5. Total factor productivity growth and risk-taking.

Predicted risk-taking proxies, $\bar{\sigma}_{c}$ and $\bar{\Omega}_{c}$, and country average total factor productivity growth. The measures have been computed for the sample 1992-2000, using the Compustat Global Industrial/Commercial database. The fitted line represents the slope from a quintile regression of TFP growth on constant and the risk-taking proxy.
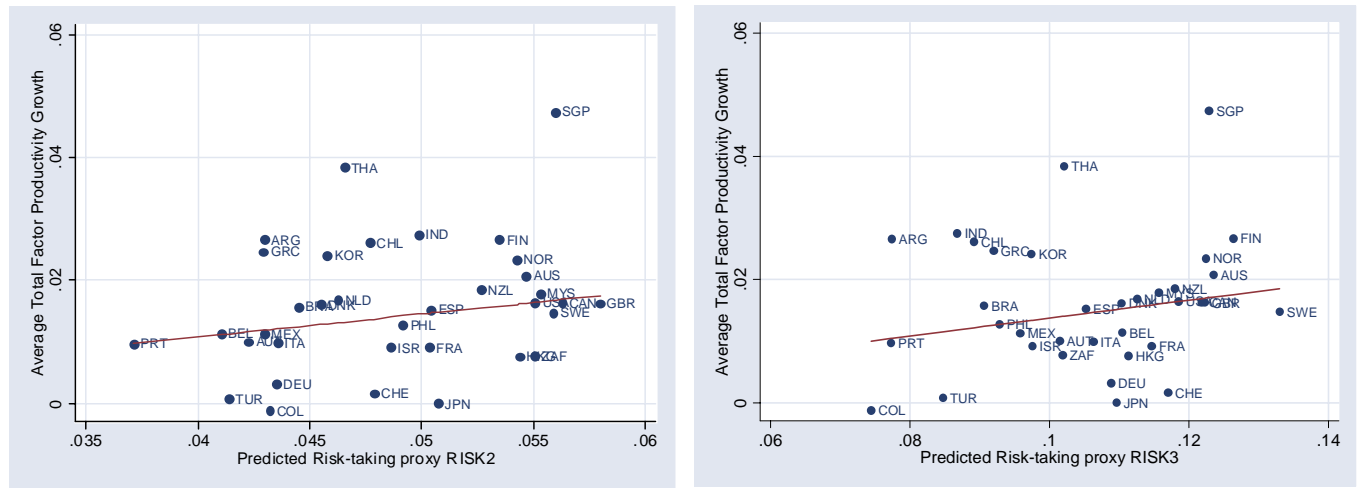